\title{
Article \\ Frataxins Emerge as New Players of the Intracellular Antioxidant Machinery
}

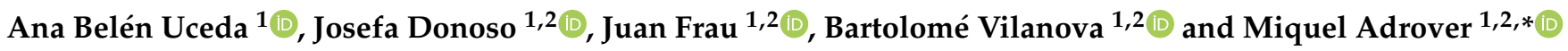 \\ 1 Departament de Química, Institut Universitari d'Investigació en Ciències de la Salut (IUNICS), Universitat de \\ les Illes Balears, Ctra. Valldemossa km 7.5, E-07122 Palma de Mallorca, Spain; ana.uceda@uib.es (A.B.U.); \\ josefa.donoso@uib.es (J.D.); juan.frau@uib.es (J.F.); bartomeu.vilanova@uib.es (B.V.) \\ 2 Institut d'Investigació Sanitària de les Illes Balears (IdISBa), E-07120 Palma de Mallorca, Spain \\ * Correspondence: miquel.adrover@uib.es; Tel.: +34-971-173491
}

Citation: Uceda, A.B.; Donoso, J.;

Frau, J.; Vilanova, B.; Adrover, M.

Frataxins Emerge as New Players of the Intracellular Antioxidant

Machinery. Antioxidants 2021, 10, 315.

https://doi.org/10.3390/

antiox10020315

Academic Editor: Claus Jacob

Received: 31 December 2020

Accepted: 18 February 2021

Published: 20 February 2021

Publisher's Note: MDPI stays neutral with regard to jurisdictional claims in published maps and institutional affiliations.

Copyright: (c) 2021 by the authors. Licensee MDPI, Basel, Switzerland. This article is an open access article distributed under the terms and conditions of the Creative Commons Attribution (CC BY) license (https:/ / creativecommons.org/licenses/by/ $4.0 /)$.

\begin{abstract}
Frataxin is a mitochondrial protein which deficiency causes Friedreich's ataxia, a cardioneurodegenerative disease. The lack of frataxin induces the dysregulation of mitochondrial iron homeostasis and oxidative stress, which finally causes the neuronal death. The mechanism through which frataxin regulates the oxidative stress balance is rather complex and poorly understood. While the absence of human (Hfra) and yeast (Yfh1) frataxins turn out cells sensitive to oxidative stress, this does not occur when the frataxin gene is knocked-out in E. coli. To better understand the biological roles of Hfra and Yfh1 as endogenous antioxidants, we have studied their ability to inhibit the formation of reactive oxygen species (ROS) from $\mathrm{Cu}^{2+}$ - and $\mathrm{Fe}^{3+}$-catalyzed degradation of ascorbic acid. Both proteins drastically reduce the formation of ROS, and during this process they are not oxidized. In addition, we have also demonstrated that merely the presence of Yfh1 or Hfra is enough to protect a highly oxidation-prone protein such as $\alpha$-synuclein. This unspecific intervention (without a direct binding) suggests that frataxins could act as a shield to prevent the oxidation of a broad set of intracellular proteins, and reinforces that idea that frataxin can be used to prevent neurological pathologies linked to an enhanced oxidative stress.
\end{abstract}

Keywords: frataxins; copper; iron; metal-catalyzed oxidation; $\alpha$-synuclein; reactive oxygen species

\section{Introduction}

Friedreich's ataxia (FRDA) is a neurodegenerative disease which prevalence strongly varies between different countries and even within the same country (from 1:20.000 to 1:150.000) [1]. It is characterized by an unsteady posture, falling, and a progressive difficulty in walking due to an impaired ability to coordinate movements [2]. FRDA appears as a result of an abnormal expansion of the GAA trinucleotide repeat in the first intron of the nuclear FXN gene [3]. Usually, healthy persons have roughly 6 to 36 repeats, whereas FRDA patients have a number of repeats ranging from 600 to 900 [4]. This gene expansion leads to lower expression levels of frataxin, a small acidic protein $(\mathrm{pI} \sim 4.9)$ conserved from bacterial to mammals [5]. Frataxin is present in all human cells, although higher levels are found in the heart and in the spinal cord, mostly in their mitochondrial membrane [3].

Human frataxin is one of the 850 proteins encoded in the nucleus and then directed to the mitochondrial membrane ([6]). Although it is firstly synthesized as a precursor protein (1-210), frataxin is then cut to form the mature form (81-120) [7]. Its structure contains two different regions: an intrinsically disordered $N$-terminal tail (81-90), and a C-terminal region (91-210; Hfra) with a well-defined globular fold that comprises two $\alpha$-helices packed against a central anti-parallel $\beta$-sheet [8] (Figure S1A). The $N$-terminal region is absent in prokaryotes and poorly conserved in eukaryotes [9], whereas the C-terminal region is highly conserved throughout species, indicating that most of their residues must be essential either for the folding or for the function (Figure S1B). In fact, the $\alpha-\beta-\alpha$ structure 
of the C-terminal region of Hfra is almost identical in yeast and bacterial frataxins (Yfh1 and CyaY, respectively) (Figure S1A).

All frataxins hold a hydrophobic region located at the $\beta$-sheet stretch, but also a negatively charged region on helix 1 (Figure S2), responsible for their metal binding, which occur through the clustered Asp and Glu residues [10]. However, little differences between the conserved C-terminal sequences of CyaY, Yfh1 and Hfra (Figure S1B) affect to their binding affinities. CyaY and Yhf1 bind $\mathrm{Fe}^{2+}$ at protein:metal ratios of 1:2, and with a higher affinity than Hfra, which binds seven $\mathrm{Fe}^{2+}$ cations. Hfra- $\mathrm{Fe}^{3+}$ complex has a higher affinity than the Hfra- $\mathrm{Fe}^{2+}$ complex, although sharing the same stoichiometry. A 1:7 stoichiometry was also observed for the CyaY-Fe ${ }^{3+}$ complex, although this protein has also lower affinity regions that makes it capable to bind up to $25 \mathrm{Fe}^{3+}$ cations. On the other hand, Yfh1 is able to form a 1:1 complex with $\mathrm{Fe}^{3+}$, but its affinity is lower than that displayed by the Hfra- $\mathrm{Fe}^{3+}$ and $\mathrm{Yfh} 1-\mathrm{Fe}^{2+}$ complexes. In addition to iron, frataxins can also bind other cations such as $\mathrm{Mn}^{2+}, \mathrm{Cu}^{+}, \mathrm{Cu}^{2+}[11]$, or even $\mathrm{Co}^{2+}$ or $\mathrm{Eu}^{3+}$ [12]. In fact, the Yfh1- $\mathrm{Cu}^{+} / \mathrm{Cu}^{2+}$ affinities are higher than those shown by Yfh1 towards the $\mathrm{Fe}^{2+} \mathrm{Fe}^{3+}$ cations (Table S1).

The affinity between frataxins and iron has let to consider them as iron binding proteins. Indeed, most of their biological roles are related with the iron metabolism [13], and as a result, frataxin deficiency causes a strong intracellular iron dysregulation [14].

Frataxin was initially suggested to keep iron in a bio-available form since ferritin could partially complement its lack [15]. This hypothesis was supported by the formation of iron-induced Yfh1 oligomers, able to transfer iron to other proteins [16]. Nevertheless, the formation of these oligomers have not been detected for Hfra [4].

In addition, Yfh1 seemed to be also involved in the heme biosynthesis [17] through a direct interaction with ferrochelatase [18]. However, healthy and FRDA patients did not show differences in the heme synthesis levels [19], although Hfra is able to interact with ferrochelatase in the presence of iron [20].

It was also observed that the Yfh1 deficiency decreased the activity of the Fe-S clustercontaining enzymes [21,22], which let to suggest that frataxins are also involved in the biosynthesis of the Fe-S clusters. The Fe-S clusters are formed on ISCU, a scaffold protein that takes persulfide from the NFS1 cysteine desulfurase, and electrons from the ferrodoxin FDX2, which reduce persulfide into sulfide. Yfh1 and Hfra bind the complex assembly [23], acting either as iron donors for the cluster assembly and/or as regulators of the entry of iron to ISCU [13]. Recently, the involvement of frataxin in the Fe-S cluster assembly has been clarified even more, as it has been proved that Hfra accelerates the persulfide transfer [24,25] while CyaY acts as an inhibitor of this process [13].

An equally relevant but yet less explored function of frataxin is its role as part of the mitochondrial machinery against oxidative stress. FDRA patients accumulate intracellular iron-protein deposits, but likely other metal-containing precipitates as the levels of zinc, copper, manganese, or aluminum were abnormally increased in a Drosophila model of FRDA [26]. These deposits induce the formation of reactive oxygen species (ROS) and trigger the oxidative stress $[27,28]$, a key factor for the development of the neurodegeneration linked to FDRA. These ROS might also be responsible for the DNA damage linked to FRDA [29], which repair is also hampered by the lack of frataxin [30].

Therefore, it seems clear that frataxin must have a crucial role as protector against the mitochondrial oxidative stress. This plausible mechanism of action is supported by the increased cell resistance to oxidative stress and to iron accumulation linked to frataxin overexpression [31]. However, the mechanism through which frataxin displays this protective role is not fully understood yet. ROS accumulation in yeast, Drosophila, mice, and FRDA cells $[28,32]$ let to suggest that frataxin deficiency might induce a deregulation of the cellular antioxidant defenses. In fact, frataxin deficiency silences the activation of the transcription factor Nrf2 [33,34], responsible for regulating several antioxidant genes in neurons [35]. Differently to healthy controls, superoxide dismutases (SODs) are not upregulated in FRDA patients treated with low doses of $\mathrm{H}_{2} \mathrm{O}_{2}$ and iron [36]. Moreover, the activities of SODs are notably enhanced upon interaction with Yfh1, which confirms 
the participation of this frataxin orthologue in the defense against oxidative stress [37]. In addition, frataxin deficiency decreases the total glutathione levels [32], while depleting the aconitase activity and disrupting the mitochondrial Fe-S cluster biogenesis [38].

Although it is clear that frataxin participates in the fine tuning of the cellular antioxidant machinery, it has not been investigated if frataxins are, per se, an active part of it. Evidence suggests their direct participation, which must be directly related to their metal-chelating ability (Table S1). Yfh1 reduces the formation of ROS from a Fe${ }^{2+} / \mathrm{H}_{2} \mathrm{O}_{2}$ reaction mixture [39], whereas CyaY can attenuate the production of $\mathrm{OH}^{\bullet}$ radicals [40]. However, the knock-out of the FXN homolog gene in E. coli, did not affect the cellular sensitivity to oxidants, which proves that CyaY must not be directly involved in the cellular protection against oxidative stress [41]. This is not the case of Hfra or Yfh1, whose absence confers cellular sensitivity to oxidative stress [27,31]. In addition, it has also been shown that extramitochondrial frataxin regulates the cytoplasmic oxidative balance [42]. Moreover, a Tat-fused Hfra, capable to penetrate the blood-brain barrier, is able to protect the dopaminergic neurons against oxidative stress [43] and also restore the activity of frataxin-depleted neurons [44].

Here, we aim to better understand the molecular mechanism through which Hfra and Yfh1 directly act against the oxidative stress. Therefore, we have studied their ability to inhibit $\mathrm{ROS}$ formation from $\mathrm{Fe}^{3+}$ - and $\mathrm{Cu}^{2+}$ - catalyzed ascorbic acid (AA) degradation, and their potential to protect other cytoplasmatic oxidation-prone proteins (e.g., $\alpha$-synuclein, used here as a model). Our results unequivocally prove that both proteins have powerful antioxidant features, at the same time that act as potent shields to unspecifically prevent the oxidation of other proteins. Consequently, and for the first time, our findings point to frataxin as a main player of the antioxidant intracellular machinery.

\section{Materials and Methods}

\subsection{Chemicals and Reagents}

All chemicals and reagents were analytical grade and they were purchased either from Sigma-Aldrich (St. Louis, MO, USA) or from Acros Organics (Geel, Belgium). Moreover, all of them were used as received without further purification. All solutions used in this study were prepared by using milli-Q water.

\subsection{Yeast Frataxin ( $Y$ fh1) Expression and Purification}

Recombinant mature yeast frataxin from Saccharomyces cerevisiae (a 123-amino acid protein that included an additional $\mathrm{N}$-terminal Met; Yfh1) was produced as described elsewhere [45]. Yfh1 was expressed in E. coli BL21(DE3) cells. These transformed cells were grown at $37^{\circ} \mathrm{C}$ in a sterilized Luria Bertani media (LB) $(25 \mathrm{~g} / \mathrm{L})$ containing ampicillin $(100 \mu \mathrm{g} / \mathrm{mL})$ while shaking at $180 \mathrm{rpm}$. At $\mathrm{OD}_{600 \mathrm{~nm}} \sim 0.6$, Yfh1 expression was induced with isopropyl- $\beta$-D-1-thiogalactopyranoside (IPTG) $(1 \mathrm{mM})$ and further incubated for $6 \mathrm{~h}$ at $37^{\circ} \mathrm{C}$ and $180 \mathrm{rpm}$. Afterwards, cells were harvested by centrifugation and re-suspended in lysis buffer (10 mM Tris-HCl, 1 mM EDTA, 1 mM PMSF, pH 8.0) and lysed by five cycles of sonication to liberate the protein and disrupt the DNA. Then, the suspension was centrifuged (at $4{ }^{\circ} \mathrm{C}$ and $4000 \mathrm{rpm}$ during $30 \mathrm{~min}$ ) and the soluble overexpressed protein was purified by two $\left(\mathrm{NH}_{4}\right)_{2} \mathrm{SO}_{4}$ precipitation steps with a $40 \%$ cut to eliminate undesirable proteins, and a $65 \%$ cut to precipitate Yfh1. After this precipitation step, Yfh1 was subjected to an anion exchange chromatography using a Pharmacia Q-Sepharose column with a gradient to $1 \mathrm{M} \mathrm{NaCl}$ (the protein eluted at $\sim 600 \mathrm{mM} \mathrm{NaCl}$ ). The final purification step included a Pharmacia phenyl-sepharose column with a decreasing $1 \mathrm{M}$ $\left(\mathrm{NH}_{4}\right)_{2} \mathrm{SO}_{4}$ gradient (the protein eluted at $\left.\sim 800 \mathrm{mM}\left(\mathrm{NH}_{4}\right)_{2} \mathrm{SO}_{4}\right)$. The purified protein was then dialyzed into the desired buffer and stored at $-25^{\circ} \mathrm{C}$ until used. The purity of the obtained Yfh1 was checked using MALDI-TOF/TOF and SDS-PAGE electrophoresis (>95\%). The concentration of Yfh1 was measured by UV-vis spectroscopy using a molar extinction coefficient estimated on the basis of its sequence: $\varepsilon_{Y f h 1 \_280 \mathrm{~nm}}=15,470 \mathrm{M}^{-1} \cdot \mathrm{cm}^{-1}$. 


\subsection{Human Frataxin (Hfra) Expression and Purification}

Since full-length mature human frataxin tends to spontaneously degrade in vitro towards smaller fragments [8], we decided to study its evolutionary conserved stretch (91-210). In any case, the $N$-terminal tail of human frataxin (81-90) is poorly conserved (Figure S1B), thus the functional region must be located at the C-terminal region (91-210; here named as Hfra).

The C-terminal domain of human frataxin (91-210; Hfra) was expressed in E. coli BL21(DE3) as fusion protein with a His-tagged glutathione $S$-transferase (GST) and a cleave site for PreScission protease, as described previously [8]. The transformed cells were grown in sterilized LB $(25 \mathrm{~g} / \mathrm{L})$ containing ampicillin $(100 \mu \mathrm{g} / \mathrm{mL})$ at $37^{\circ} \mathrm{C}$ and $180 \mathrm{rpm}$. At $\mathrm{OD}_{600 \mathrm{~nm}} \sim 0.6$, Hfra expression was induced with IPTG $(0.2 \mathrm{mM})$ and further incubated for $6 \mathrm{~h}$ at $37^{\circ} \mathrm{C}$ and $180 \mathrm{rpm}$. Afterwards, cells were harvested by centrifugation and re-suspended in lysis buffer by five cycles of sonication. Then, a Ni-NTA chromatography was applied using a nickel column and the protein was eluted with a Tris buffered solution ( $20 \mathrm{mM}$; pH 8.0) containing 0.5 M imidazol. Purified Hfra was obtained in a subsequent step using gel filtration chromatography on a Superdex-75 HR 10/300 column. Finally, the His-tag was removed using the PreScission protease according to the manufacturer protocol (GE27-0843-01; Merck, Darmstadt, Germany) and then, the purified protein was dialyzed into the desired buffer and stored at $-25{ }^{\circ} \mathrm{C}$ until used. The purity of Hfra was checked using MALDI-TOF/TOF and SDS-PAGE electrophoresis (>95\%). The concentration of Hfra was measured by UV-vis spectroscopy using a molar extinction coefficient estimated on the basis of its sequence: $\varepsilon_{\text {Hfra_2 } 280 \mathrm{~nm}}=26,930 \mathrm{M}^{-1} \cdot \mathrm{cm}^{-1}$.

\subsection{Human $\alpha$-Synuclein ( $\alpha$-syn) Expression and Purification}

Recombinant human $\alpha$-synuclein ( $\alpha$-syn) was produced as we described before [46]. In brief, E. coli BL21(DE3) transformed cells were grown in sterilized LB $(25 \mathrm{~g} / \mathrm{L})$ containing ampicillin $(100 \mu \mathrm{g} / \mathrm{mL})$ at $37^{\circ} \mathrm{C}$ and $180 \mathrm{rpm}$. At $\mathrm{OD}_{600 \mathrm{~nm}}=0.6-0.8 \alpha$-syn expression was induced with IPTG $(1 \mathrm{mM})$ and further incubated during $4 \mathrm{~h}$ at $37^{\circ} \mathrm{C}$ and $180 \mathrm{rpm}$. Afterwards, cells were centrifuged and the resulting pellet was resuspended in lysis buffer (10 mM Tris-HCl, $1 \mathrm{mM}$ EDTA, $1 \mathrm{mM}$ PMSF, $\mathrm{pH} 8.0$ ) and stirred for $1 \mathrm{~h}$ at $4{ }^{\circ} \mathrm{C}$. Cells were then lysed and the cellular debris were removed by centrifugation. Nucleic acids were removed by adding streptomycin sulfate $(1 \% \mathrm{w} / v)$ and stirring for $1 \mathrm{~h}$ at $4{ }^{\circ} \mathrm{C}$, followed by centrifugation. The supernatant was supplied by the addition of $\left(\mathrm{NH}_{4}\right)_{2} \mathrm{SO}_{4}$ (up to $0.295 \mathrm{~g} / \mathrm{mL}$ ) and additionally stirred for $1 \mathrm{~h}$ at $4{ }^{\circ} \mathrm{C}$. The obtained pellet was collected by centrifugation, dissolved in $10 \mathrm{mM}$ Tris- $\mathrm{HCl}$ ( $\mathrm{pH}$ 7.4) and filtered through a $0.22 \mu \mathrm{m}$ filter. The obtained solution was loaded onto an anion exchange column (GE Healthcare RESOURCETM Q; $6 \mathrm{~mL})$ and $\alpha$-syn was eluted with a $\mathrm{NaCl}$ gradient $(0-600 \mathrm{mM})$. The purified protein was dialyzed into the desired buffer and stored at $-25^{\circ} \mathrm{C}$ until used. The purity of the obtained $\alpha$-syn was checked using MALDI-TOF/TOF and SDS-PAGE electrophoresis (>95\%). $\alpha$-Syn concentration was measured by UV-Vis spectroscopy using a molar extinction coefficient estimated on the basis of its amino acid content: $\varepsilon_{\alpha \text {-syn_280nm }}=5960 \mathrm{M}^{-1} \cdot \mathrm{cm}^{-1}$.

\subsection{Ascorbic Acid Degradation}

The degradation rate of $\mathrm{AA}(70 \mu \mathrm{M})$ was studied at different concentrations of a sodium phosphate buffer ( $\mathrm{pH}$ 7.4) (i.e., 5, 20, and $50 \mathrm{mM}$ ) that contained $150 \mathrm{mM} \mathrm{NaCl}$. In addition, the AA degradation rate was studied in a $10 \mathrm{mM}$ phosphate buffer ( $\mathrm{pH}$ 7.4) containing different concentrations of $\mathrm{NaCl}$ (i.e., 0, 50, 100, 150, and $200 \mathrm{mM}$ ).

The degradation rate of AA $(70 \mu \mathrm{M})$ was also studied in $10 \mathrm{mM}$ phosphate buffer ( $\mathrm{pH}$ 7.4) containing $150 \mathrm{mM}$ of $\mathrm{NaCl}(I=172.4 \mathrm{mM}$; from now named as buffer B1). The AA was alone or in the presence of $2.5 \mu \mathrm{M}$ of $\mathrm{Cu}^{2+}$ or $2.5 \mu \mathrm{M}$ of $\mathrm{Fe}^{3+}$. These reactions were also studied in the presence of $\sim 5 \mu \mathrm{M}$ EDTA. The degradation rate of AA $(70 \mu \mathrm{M})$ in the presence of $2.5 \mu \mathrm{M}$ of $\mathrm{Cu}^{2+}$ was also studied under anaerobic conditions. To carry out this experiment, aliquots of buffer $\mathrm{B} 1$ containing $\mathrm{Cu}^{2+}$ were subjected to $\mathrm{N}_{2}$ gas bubbling during 15 min. Afterwards, the AA was added and immediately, the AA degradation rate 
measured. The concentration of molecular oxygen in solution was measured in triplicate (for the studies carried out under aerobic but also anaerobic conditions) using a fiber-optic oxygen meter FireStingO2/FSO2-4 (PyroScience GmbH, Aachen, Germany) coupled to an oxygen probe (OXROB10).

All the reaction mixtures were prepared taking aliquots from an AA stock solution $(3 \mathrm{mM})$ prepared in milli-Q water and stored in the dark at $4{ }^{\circ} \mathrm{C}$ during less than two days. In addition, we also used aliquots taken from stock solutions containing EDTA-Na 2 $(100 \mu \mathrm{M})$ prepared in buffer $\mathrm{B} 1 ; \mathrm{CuCl}_{2}$ or $\mathrm{FeCl}_{3}(100 \mu \mathrm{M})$ prepared in milli-Q water from more concentrated solutions $\left(20 \mathrm{mM} \mathrm{CuCl}_{2}\right.$ or $\mathrm{FeCl}_{3}$ in $40 \mathrm{mM}$ glycine, a weak metal chelator used to avoid the formation of insoluble hydroxyls when adding the metal cations to the buffer B1 [47].

The degradation rate of AA $(70 \mu \mathrm{M})$ in buffer B1 was also studied in the presence of Hfra $(10 \mu \mathrm{M})$ or Yfh1 (at $0.5,1$ and $2.5 \mu \mathrm{M})$. In these assays, the protein was alone or in the co-presence of $\mathrm{Cu}^{2+}(2.5 \mu \mathrm{M})$ or $\mathrm{Fe}^{3+}(2.5 \mu \mathrm{M})$.

The temporal changes in the AA concentration were measured at $256 \mathrm{~nm}$ during $150 \mathrm{~min}$, using a $1 \mathrm{~cm}$ quart cell and a Shimadzu UV-2401-PC double beam spectrophotometer (Shimadzu Europa GmbH, Duisburg, Germany). The absorbance of the buffer B1 was subtracted from the measurements. All the experiments were run in triplicate at $25^{\circ} \mathrm{C}$.

\subsection{Dynamic Light Scattering (DLS) Measurements}

DLS measurements of protein size distributions were performed using a Zetasizer Nano instrument (Malvern Instruments, Malvern, UK). The experiments were run at $90^{\circ}$ scattering angle and using a laser with a wavelength of $633 \mathrm{~nm}$. Stock solutions containing $\mathrm{CuCl}_{2}(1.2 \mathrm{mM})$ or $\mathrm{FeCl}_{3}(1.2 \mathrm{mM})$ were prepared in buffer B1. These solutions were prepared from more concentrated solutions $\left(10 \mathrm{mM} \mathrm{CuCl} \mathrm{m}_{2}\right.$ or $\mathrm{FeCl}_{3}$ in $20 \mathrm{mM}$ glycine). Aliquots $(100 \mu \mathrm{L})$ from samples containing Hfra $(60 \mu \mathrm{M})$ alone or in the presence of $\mathrm{Cu}^{2+}$ or $\mathrm{Fe}^{3+}(600 \mu \mathrm{M})$ that were prepared in buffer B1, were used for DLS measurements at $25^{\circ} \mathrm{C}$. As soon as the metal cation was added to the Hfra solution, the sample was mixed and transferred to the DLS cuvette to start the measurement. Each measurement included the accumulation of 30 different correlation curves.

\subsection{Superoxide Anion $\left(\mathrm{O}_{2}^{\bullet-}\right)$ Formation}

Nitroblue tetrazolium (NBT) was used to monitor the time-dependent formation of $\mathrm{O}_{2}{ }^{\bullet-}$ during the $\mathrm{Fe}^{3+}$-catalyzed AA degradation. Once $\mathrm{O}_{2}{ }^{\bullet-}$ is formed, it rapidly reacts with NBT to yield formazan, which increases the absorbance of the overall solution at $560 \mathrm{~nm}[48,49]$. A reaction mixture containing AA $(70 \mu \mathrm{M}), \mathrm{Fe}^{3+}(2.5 \mu \mathrm{M})$ and NBT $(50 \mu \mathrm{M})$ was prepared in $10 \mathrm{mM}$ sodium phosphate buffer at $\mathrm{pH} 7.4$. The UV-vis spectra of this reaction mixture were recorded at different incubation times (at $25^{\circ} \mathrm{C}$ ) using a $1 \mathrm{~cm}$ plastic cell and a Shimadzu UV-2401-PC double beam spectrophotometer (Shimadzu Europa GmbH, Duisburg, Germany). The absorbance of the buffer was subtracted from the measurements. Experiments were run in duplicate.

\subsection{Hydrogen Peroxide $\left(\mathrm{H}_{2} \mathrm{O}_{2}\right)$ Formation}

The effect of Yfh1 and Hfra on the $\mathrm{H}_{2} \mathrm{O}_{2}$ formation was studied using the red peroxidase kit assay (MAK165; Sigma-Aldrich, St. Louis, MO, USA). Red peroxidase substrate (RS) is a non-fluorescent compound that reacts with $\mathrm{H}_{2} \mathrm{O}_{2}$ (1:1) in the presence of horseradish peroxidase (HRP) to form the fluorescent resorufin. RS was reconstituted with $250 \mu \mathrm{L}$ of DMSO, whereas HRP was reconstituted with $1 \mathrm{~mL}$ of the assay buffer $(20 \mathrm{U} / \mathrm{mL})$. A solution containing $50 \mu \mathrm{L}$ of the RS stock solution, $200 \mu \mathrm{L}$ of the HRP stock solution, and $4.75 \mathrm{~mL}$ of the assay buffer was prepared (master mix; MX). The time-dependent $\mathrm{H}_{2} \mathrm{O}_{2}$ formation was measured on $50 \mu \mathrm{L}$ of samples containing AA $(70 \mu \mathrm{M})$ and $\mathrm{Cu}^{2+}$ $(2.5 \mu \mathrm{M})$ or $\mathrm{Fe}^{3+}(2.5 \mu \mathrm{M})$, in the absence or in the presence of Hfra and Yfh1 at $0.5,2.5$, and $10 \mu \mathrm{M}$ concentrations. In all preparations, AA was the final reagent added before starting the fluorescence measurements, which were recorded during $150 \mathrm{~min}$. Assay buffer 
was used as background fluorescence and subtracted from the data. Control experiments without $\mathrm{Cu}^{2+}$ or $\mathrm{Fe}^{3+}$, and without AA were also done. The concentrations of $\mathrm{H}_{2} \mathrm{O}_{2}$ in the reaction mixtures were determined from a standard calibration curve, obtained using freshly prepared $\mathrm{H}_{2} \mathrm{O}_{2}$ solutions with concentrations of $0,0.5,2,4,10,20,30$, and $50 \mu \mathrm{M}$ (prepared from a $20 \mathrm{mM} \mathrm{H}_{2} \mathrm{O}_{2}$ stock solution). $50 \mu \mathrm{L}$ of the different $\mathrm{H}_{2} \mathrm{O}_{2}$ stock solutions were mixed with $50 \mu \mathrm{L}$ of the MX solution, incubated $30 \mathrm{~min}$ at $25{ }^{\circ} \mathrm{C}$ and afterwards, their fluorescence intensities were recorded. All fluorescence measurements were done in triplicate at $25^{\circ} \mathrm{C}$ on a Varian Cary Eclipse fluorescence spectrophotometer (Agilent, Santa Clara, CA, USA) using 96-well plates $\left(\lambda_{\text {exc }} 540 \mathrm{~nm} ; \lambda_{\text {em }} 590 \mathrm{~nm}\right)$.

\subsection{Total Free Radical Formation from $\mathrm{Cu}^{2+}$ - and $\mathrm{Fe}^{3+}$-Catalyzed AA Degradation}

A fluorescein stock solution ( $2 \mathrm{mM}$ ) was prepared in buffer B1 and added to a final concentration of $26 \mu \mathrm{M}$ to reaction mixtures containing AA $(70 \mu \mathrm{M})$ alone or in the presence of $2.5 \mu \mathrm{M} \mathrm{Cu}^{2+}$ or $\mathrm{Fe}^{3+}$, which were prepared in buffer B1. These mixtures were also studied in the presence of 0.5 or $10 \mu \mathrm{M}$ Hfra and Yfh1. The temporal variation of the fluorescence signal at $518 \mathrm{~nm}\left(\lambda_{\text {exc }} 490 \mathrm{~nm}\right)$ was followed during $150 \mathrm{~min}$. All the experiments were run in duplicated at $25^{\circ} \mathrm{C}$ using a Varian Cary Eclipse fluorescence spectrophotometer and quartz cells of $1 \mathrm{~cm}$ path length.

\subsection{Analysis of the Formation of the Hydroxyl Radical $\left(\mathrm{HO}^{\bullet}\right)$}

The effect of Hfra and $\mathrm{Yfh} 1$ on the formation of $\mathrm{HO}^{\bullet}$ was studied using the coumarin3-carboxylic acid (3-CCA). In the presence of $\mathrm{HO}^{\bullet}, 3$-CCA is rapidly oxidized to the fluorescent 7-hydroxy-coumarin-3-carboxylic acid (7-OH-CCA) $\left(\lambda_{\text {max_exc }} 395 \mathrm{~nm}\right.$; $\lambda_{\text {max_em }}$ $450 \mathrm{~nm}$ ), thus allowing to record the time-dependent $\mathrm{HO} \bullet$ formation [50]. A 3-CCA stock solution $(20 \mathrm{mM}$ ) was prepared in $20 \mathrm{mM}$ sodium phosphate buffer ( $\mathrm{pH} 9.0$ ) and added to a final concentration of $100 \mu \mathrm{M}$ to reaction mixtures that always contained $70 \mu \mathrm{M}$ AA and $2.5 \mu \mathrm{M} \mathrm{Cu}^{2+}$ or $\mathrm{Fe}^{3+}$. The $\mathrm{AA} / \mathrm{Cu}^{2+}$ reaction mixtures were also prepared in the presence of $10 \mu \mathrm{M}$ Hfra or $0.5 \mu \mathrm{M}$ Yfh1. Solutions containing $70 \mu \mathrm{M}$ AA or $2.5 \mu \mathrm{M} \mathrm{Cu}^{2+}$ alone were used as controls. The temporal variation of the fluorescence signal at $450 \mathrm{~nm}$ was followed during $150 \mathrm{~min}$. All the experiments were run in triplicate or higher at $25^{\circ} \mathrm{C}$ using a Varian Cary Eclipse fluorescence spectrophotometer (Agilent, Santa Clara, CA, USA) and quartz cells of $1 \mathrm{~cm}$ path length.

\subsection{MALDI-TOF/TOF MS Study of the Effect of Reactive Oxygen Species (ROS) on the Molecular Weight of Frataxins and $\alpha$-Synyclein}

MALDI-TOF/TOF studies were performed on a Bruker Autoflex III MALDI-TOF/TOF spectrometer (Bruker, Billerica, MA, USA) equipped with a 200-MHz smart-beam pulsed $\mathrm{N} 2$ laser $(\lambda 337 \mathrm{~nm}$ ). Aliquots of $1 \mu \mathrm{L}$ of mixtures containing $10 \mu \mathrm{M}$ or $5 \mu \mathrm{M}$ protein (Hfra, Yfh1 and/or $\alpha$-syn), $70 \mu \mathrm{M}$ AA and $2.5 \mu \mathrm{M} \mathrm{Cu}^{2+}$ or Fe ${ }^{3+}$ prepared in buffer B1, were taken after 0 and $150 \mathrm{~min}$ of incubation $\left(25^{\circ} \mathrm{C}\right)$ and supplemented by trifluoroacetic acid (TFA) $(0.2 \% v / v)$. Samples were then combined with $1 \mu \mathrm{L}$ of matrix solution $(10 \mu \mathrm{g}$ of sinapinic acid in a solution water:acetonitrile (70:30) containing $0.1 \%$ TFA), and a $0.5 \mu \mathrm{L}$ aliquot of this mixture was spotted onto a steel target plate (MTP 384), air-dried and subjected to mass determination. The IS1 and IS2 voltages were $20 \mathrm{kV}$ and $18.5 \mathrm{kV}$ respectively, and the lens voltage was $7.5 \mathrm{kV}$. Measurements were performed using a positive reflector mode with matrix suppression below $400 \mathrm{Da}$. The spectra were calibrated externally using a protein calibration standard (3600-17,000 Da) from Bruker. The experiments were performed in duplicate.

\subsection{Fluorescence Study of the Di-Tyrosine Formation}

The Tyr-Tyr crosslinking was studied on reaction mixtures containing $70 \mu \mathrm{M}$ of AA, $2.5 \mu \mathrm{M}$ of $\mathrm{Cu}^{2+}$ or $\mathrm{Fe}^{3+}$, and $10 \mu \mathrm{M}$ of Hfra or Yfh1. These reaction mixtures were prepared in buffer $\mathrm{B} 1$ and incubated at $25{ }^{\circ} \mathrm{C}$ during $150 \mathrm{~min}$. The formation of di-Tyr involves the loss of the Tyr fluorescence signal $\left(\lambda_{\text {max_em }} \sim 305 \mathrm{~nm}\right)$ concomitant with an increase in the 
fluorescence emission intensity between $405-410 \mathrm{~nm}$ [51]. Consequently, the fluorescent spectra of the different reaction mixtures were acquired between 375 and $525 \mathrm{~nm}\left(\lambda_{\text {exc }}\right.$ $325 \mathrm{~nm}$ ) before and after incubation using a Varian Cary Eclipse fluorescence spectrophotometer and quartz cells of $1 \mathrm{~cm}$ path length. Experiments were performed in duplicate.

\subsection{Scavenging Capacity of Hfra, Yfh1, and $\alpha$-Syn on the HO• Radical}

The cupric reducing antioxidant capacity (CUPRAC) method was applied to analyze the ability of the different proteins to trap the $\mathrm{HO}^{\bullet}$ radical $[52,53]$. CUPRAC method involves the formation of $\mathrm{HO}^{\bullet}$ as a result of the reaction between $\mathrm{Fe}^{2+}$ and $\mathrm{H}_{2} \mathrm{O}_{2}$. After this reaction is completed, the latter is degraded using catalase to avoid chemical interferences during the determination. $\mathrm{HO}^{\bullet}$ can hydroxylate salicylic acid, which is able to reduce the neocuproine- $\mathrm{Cu}^{2+}$ to neocuproine- $\mathrm{Cu}^{+}$(yellow; $\lambda_{\text {abs_max }} 450 \mathrm{~nm}$ ). If the different proteins are able to react with $\mathrm{HO}^{\bullet}$, this would avoid the hydroxylation of salicylic acid and consequently, the formation of the $\mathrm{UV}$-active neocuproine- $\mathrm{Cu}^{+}$complex.

For this study, stock solutions of salicylic acid $(10 \mathrm{mM}), \mathrm{FeCl}_{2}(20 \mathrm{mM}$ in milli-Q water containing $40 \mu \mathrm{L}$ of $\mathrm{HCl} 1 \mathrm{M}$ for each ml of solution), EDTA $(20 \mathrm{mM}), \mathrm{H}_{2} \mathrm{O}_{2}(10 \mathrm{mM}), \mathrm{CuCl}_{2}$ $(10 \mathrm{mM})$, and $\mathrm{AcNH}_{4}(1 \mathrm{M})$ were prepared in milli-Q water. Additionally, neocuproine $(7.5 \mathrm{mM})$ was prepared in ethanol, whereas a catalase solution $(298 \mathrm{U} / \mathrm{mL})$ was prepared in buffer B1. All stock solutions were stored at $4{ }^{\circ} \mathrm{C}$ in dark until use. Initially, reaction mixtures containing $0.5 \mathrm{mM}$ salicylic acid, $0.5 \mathrm{mM} \mathrm{Fe}^{2+}, 0.5 \mathrm{mM}$ EDTA, and $0.5 \mathrm{mM} \mathrm{H}_{2} \mathrm{O}_{2}$, in the absence or in the presence of $\alpha$-syn $(10 \mu \mathrm{M})$, Hfra $(10 \mu \mathrm{M})$, Yfh1 $(10 \mu \mathrm{M}), \alpha$-syn $(10 \mu \mathrm{M})+$ Hfra $(10 \mu \mathrm{M})$ or $\alpha$-syn $(10 \mu \mathrm{M})+$ Yfh1 $(10 \mu \mathrm{M})$, were prepared in the buffer B1 and incubated during $10 \mathrm{~min}$ at $37^{\circ} \mathrm{C}$ and at $500 \mathrm{rpm}$. Afterwards, catalase was added to a final concentration of $15 \mathrm{U} / \mathrm{mL}$ and further incubated during 30 min under the same conditions. Later on, $100 \mu \mathrm{L}$ of the resulting mixtures were diluted in $1 \mathrm{~mL}$ of milli-Q water containing $1 \mathrm{mM}$ of $\mathrm{Cu}^{2+}, 0.75 \mathrm{mM}$ of neocuproine and $0.2 \mathrm{M}$ of $\mathrm{AcNH}_{4}$. These solutions were incubated during $2.5 \mathrm{~h}$ at room temperature and their $\mathrm{UV}$-vis spectrum were recorded at $25^{\circ} \mathrm{C}$ using a $1 \mathrm{~cm}$ quartz cell and a Shimadzu UV-2401-PC double beam spectrophotometer (Shimadzu Europa GmbH, Duisburg, Germany). The absorbance of a $1 \mathrm{~mL}$ mixture containing $1 \mu \mathrm{M}$ of $\mathrm{Cu}^{2+}, 0.75 \mu \mathrm{M}$ of neocuproine, $0.2 \mathrm{M}^{2} \mathrm{AcNH}_{4}$ and $100 \mu \mathrm{L}$ of milli-Q water was subtracted from the measurements. Experiments were run in duplicate.

\subsection{Study of the Interactions between Hfra and Yfh1 with $\alpha$-Syn}

The bindings of Hfra and Yfh1 with $\alpha$-syn were studied by chemical cross-linking experiments, carried out using the ethylene glycol bis-succinimidyl succinate (EGS). Reaction mixtures prepared in buffer B1 contained: (i) $10 \mu \mathrm{M} \alpha$-syn; (ii) $10 \mu \mathrm{M}$ Hfra: (iii) $10 \mu \mathrm{M}$ Yfh1: (iv) $10 \mu \mathrm{M} \alpha$-syn and $10 \mu \mathrm{M}$ Hfra; and (v) $10 \mu \mathrm{M} \alpha$-syn and $10 \mu \mathrm{M}$ Yfh1. These mixtures were incubated in the absence and in the presence of $0.1 \mathrm{mM}$ EGS during $30 \mathrm{~min}$ at $25^{\circ} \mathrm{C}$. Afterwards, the reactions containing EGS were quenched by the addition of $50 \mathrm{mM}$ Tris (pH 7.5) and further incubated during $15 \mathrm{~min}$ at $25^{\circ} \mathrm{C}$. The obtained samples were analyzed using SDS-PAGE electrophoresis and stained using silver staining. Additionally, all the reaction mixtures were analyzed by MALDI-TOF/TOF using the experimental approach already described before.

\subsection{Sodium Dodecyl Sulfate-Polyacrylamide Gel Electrophoresis}

Sodium dodecyl sulfate-polyacrylamide gel electrophoresis (SDS-PAGE) studies carried out in this work were performed by taking $15 \mu \mathrm{L}$ of the different samples that were analyzed and mixed with $15 \mu \mathrm{L}$ of Laemmli sample buffer (Bio-Rad, Hercules, CA, USA). The resulting mixture was then loaded onto 4-20\% Mini-Protean TGX precast gels (Bio-Rad, Hercules, CA, USA). The gels were subjected to a voltage of $200 \mathrm{~V}$ for $45 \mathrm{~min}$ at room temperature using running buffer (100 $\mathrm{mM}$ Tris, $100 \mathrm{mM}$ glycine and $0.1 \% \mathrm{SDS})$. Proteins were visualized with silver staining (Thermo Scientific, Waltham, MA, USA). 


\section{Results and Discussion}

\subsection{Degradation Rate of Ascorbic Acid Depends on the Concentrations of Phosphate and $\mathrm{NaCl}$}

FDRA patients have an unbalance in the iron homeostasis [26,54] and an expanded intracellular cooper distribution [55]. This unavoidably trigger an increase of the free radical release and therefore, an enhanced oxidative stress, directly linked to the pathogenesis of FRDA [28]. These findings let us to suggest a rather trivial but yet unproven hypothesis: the metal-chelating ability of frataxins could also be part of the cellular machinery against oxidative stress.

To investigate this possibility, we took as reactions model the $\mathrm{Cu}^{2+}$ - and $\mathrm{Fe}^{3+}$-catalyzed ascorbic acid (AA) degradations. AA is present at high concentrations in cells, especially in neurons $(\sim 10 \mathrm{mM})$, where it scavenges reactive oxygen species (ROS) [56,57]. However, if free $\mathrm{Fe}^{3+}$ and $\mathrm{Cu}^{2+}$ cations are present, they form complexes with $\mathrm{AA}$, stimulating its oxidation while producing ROS (Figure 1) [58,59].

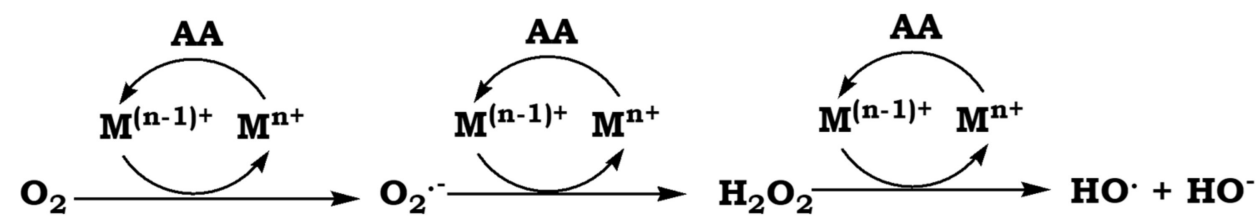

Figure 1. Reaction cycle for the production of ROS from molecular oxygen and AA [60]. $\mathrm{M}^{\mathrm{n}+}$ catalyzes the oxidation of AA to dehydroascorbic acid through the formation of a $\mathrm{M}^{\mathrm{n}+}-\mathrm{AA}$ complex, which binds to $\mathrm{O}_{2}$. In the complex, $\mathrm{M}^{\mathrm{n}+}$ mediates the electron transfer from AA to the $\mathrm{O}_{2}$ in a series of reactions that leads to the production of superoxide anion radical $\left(\mathrm{O}_{2}{ }^{\bullet-}\right)$ and $\mathrm{H}_{2} \mathrm{O}_{2}$. In these reactions $\mathrm{M}^{\mathrm{n}+}$ is reduced to $\mathrm{M}^{(\mathrm{n}-1)+}$ and oxidized back in a Fenton-type of reaction, which constitutes the source of one electron equivalent required for the reduction of $\mathrm{H}_{2} \mathrm{O}_{2}$. The final product of these reactions is $\mathrm{OH}^{\bullet}$.

The metal-catalyzed oxidation rate of AA is highly dependent on the environmental conditions [61]. Hence, before to test the effect of Yfh1 and Hfra on this reaction, we screened different phosphate ( $\mathrm{pH}$ 7.4) and $\mathrm{NaCl}$ concentrations (as we aimed to mimic the intracellular environment), to have the lowest non-catalyzed degradation rate of AA, which would diminish the relevance of this side-reaction. Its degradation rate decreased upon increasing the $\mathrm{NaCl}$ concentration (Figure S3A), likely due to the inhibitory effect of this salt on the $\mathrm{O}_{2}$-AA interaction [62]. On the contrary, phosphate seems to catalyze the AA oxidation (Figure S3B). In any case, the degradation rate of AA was always quicker than when EDTA was present, suggesting that even small metal traces might be present in solution (Figure S4A). As expected, the degradation rate of AA also depends on the concentration of molecular oxygen in the reaction mixture $(8.1 \pm 2 \mathrm{mg} / \mathrm{L})$, as it drastically decreased under anaerobic conditions (Figure S4B).

From the obtained data, we decided to perform the protein containing studies using a $10 \mathrm{mM}$ phosphate buffer supplied with $150 \mathrm{mM} \mathrm{NaCl}$. These conditions were chosen because the reduction in the degradation rate observed when using $5 \mathrm{mM}$ phosphate or $200 \mathrm{mM} \mathrm{NaCl}$ was not significant, and at the same time we better ensured a constant $\mathrm{pH}$ and a low protein aggregation rate ( $\mathrm{NaCl}$ stimulates protein aggregation) [63].

\subsection{Yfh1, but not $\mathrm{Hfra}$, Inhibits the $\mathrm{Cu}^{2+}$ - and $\mathrm{Fe}^{3+}$-Catalyzed Degradation of $\mathrm{AA}$}

$\mathrm{Cu}^{2+}$ catalyzed the oxidation of AA, and its catalytic effect was higher than that shown by $\mathrm{Fe}^{3+}$. Since this effect was completely abolished in presence of EDTA (Figure S4A), we assumed that metal-chelating proteins (e.g., Hfra or Yfh1) could act in the same way.

In fact, Yfh1 totally inhibited the degradation of AA when $\mathrm{Cu}^{2+}$ was present (AA only degraded $<0.5 \%$ after $150 \mathrm{~min}$ of incubation with $10 \mu \mathrm{M}$ Yfh1; data not shown). Its inhibitory effect had a concentration-dependent behavior (Figure 2A), and even at a Yhf1: $\mathrm{Cu}^{2+}$ ratio of 1:5, the time needed to degrade the $50 \%$ of AA increased from 10.4 to $84.4 \mathrm{~min}$. The $\mathrm{Fe}^{3+}$-catalyzed degradation of AA was also partially inhibited by Yfh1. The presence of 
Yfh1 at a 5-fold lower concentration than that of $\mathrm{Fe}^{3+}$, also enhanced the time to degrade the $50 \%$ of AA from 107 to 463 min (Figure 2B). The inhibitory effect of Yfh 1 was also observed in the absence of $\mathrm{Cu}^{2+} / \mathrm{Fe}^{3+}$ (Figure S5), which suggest that $Y$ fh1 can also chelate trace metals.
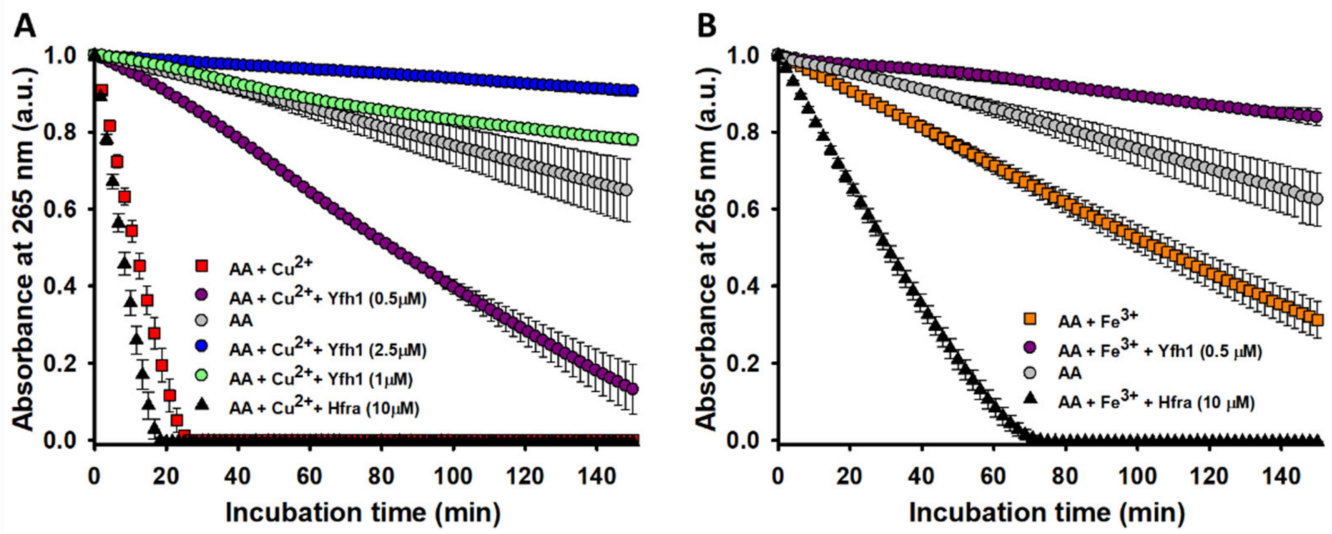

Figure 2. Effect of Hfra and $\mathrm{Yfh} 1$ on the $\mathrm{Cu}^{2+}$ - and $\mathrm{Fe}^{3+}$-catalyzed degradation rate of AA. (A) Time-dependent AA $(70 \mu \mathrm{M})$ degradation at $25^{\circ} \mathrm{C}$ measured by the decrease in its absorbance at $265 \mathrm{~nm}$ when AA was alone $(\bullet)$, in presence of $\mathrm{Cu}^{2+}(2.5 \mu \mathrm{M})(-)$, in the presence of $\mathrm{Cu}^{2+}(2.5 \mu \mathrm{M})$ and Yfh $1(0.5 \mu \mathrm{M})(\bullet)$, in the presence of $\mathrm{Cu}^{2+}(2.5 \mu \mathrm{M})$ and $\mathrm{Yfh} 1(1 \mu \mathrm{M})(\bullet)$, in the presence of $\mathrm{Cu}^{2+}$ $(2.5 \mu \mathrm{M})$ and $\mathrm{Yfh} 1(2.5 \mu \mathrm{M})(\bullet)$, and in the presence of $\mathrm{Cu}^{2+}(2.5 \mu \mathrm{M})$ and Hfra $(10 \mu \mathrm{M})(\mathbf{\Delta})$. (B) Time-dependent AA $(70 \mu \mathrm{M})$ degradation at $25^{\circ} \mathrm{C}$ measured by the decrease in its absorbance at $265 \mathrm{~nm}$ when AA was alone (•), in presence of $\mathrm{Fe}^{3+}(2.5 \mu \mathrm{M})()$, in the presence of $\mathrm{Fe}^{3+}(2.5 \mu \mathrm{M})$ and Yfh1 $(0.5 \mu \mathrm{M})(\bullet)$, and in the presence of $\mathrm{Fe}^{3+}(2.5 \mu \mathrm{M})$ and Hfra $(10 \mu \mathrm{M})(\mathbf{\Delta})$. In both panels, the data points are the mean from all the replicas, and the error bars represent standard deviation from the different independent measurements.

Hfra is able to bind $\mathrm{Cu}^{2+}$ with a slightly higher affinity than Yfh1 (Table S1). Hence, we expected a similar inhibitory effect. However, we observed a completely opposite trend. The time needed to degrade the $50 \%$ of AA in the presence of $\mathrm{Cu}^{2+}$ slightly decreased upon increasing the Hfra concentration. In fact, it decreased an $\sim 40 \%$ in presence of $10 \mu \mathrm{M}$ Hfra (Figure 2A). This effect was even more pronounced on the $\mathrm{Fe}^{3+}$-catalyzed degradation of $\mathrm{AA}$, where the presence of $10 \mu \mathrm{M}$ Hfra reduced this time in $~ 71 \%$ (Figure $2 \mathrm{~B}$ ).

Altogether, these results prove that the ability of frataxins to protect against the metalcatalyzed oxidation must depend on other factors different from their similar metal binding affinity. Yfh1 and Hfra have different propensities to form metal-induced assemblies [64]. Thus, we investigated if this could be related with their different mechanism of action on $\mathrm{Cu}^{2+} / \mathrm{Fe}^{3+}$-catalyzed AA oxidation. While $\mathrm{Cu}^{2+}$ does not induce the formation of $\mathrm{Yfh} 1$ oligomers [65], $\mathrm{Fe}^{3+}$ polymerizes Y $\mathrm{Yh} 1$ by forming different multimers working as storage compartment for $\mathrm{Fe}^{3+}$, but also as part of the iron detoxification strategy [66]. On the other hand, $\mathrm{Fe}^{3+}$ also induces the formation of unstable $\mathrm{Hfra}^{81-210}$ oligomers [67]. However, there is not data reporting the metal-induced oligomeric propensity of the short Hfra construct (91-210). DLS experiments recorded on our $\mathrm{Hfra}^{91-210}$ prove that $\mathrm{Cu}^{2+}$ is able to induce the formation of protein assemblies (with a $R h$ of $\sim 8 \mathrm{~nm}$ ), but those are smaller than those formed in the presence of $\mathrm{Fe}^{3+}$. In fact, $\mathrm{Fe}^{3+}$ clumps Hfra into two different oligomeric forms, one with $R h \sim 0.7 \mu \mathrm{m}$ and another with a $R h \sim 1.4 \mu \mathrm{m}$ (Figure S6).

The obtained results reveal that Yfh1 and Hfra have different ability to protect AA (but also likely other cellular compounds prompt to be degraded through a metal-catalyzed mechanism). While Yfh1 acts as strong antioxidant, Hfra alone (Figure S5) but especially Hfra-metal complexes, seem to have an enhanced capacity to catalyze the AA degradation. This difference cannot be ascribed to a different metal binding ability (Yfh1 and Hfra have similar $\mathrm{Fe}^{3+}$ affinities) nor to a different metal-induced oligomeric propensity (Yhf1 and Hfra form oligomers in presence of $\mathrm{Fe}^{3+}$ ). Consequently, other sequentially/structural 
factors, or even differences in the geometries of the complexes, might be behind the differences observed between Yfh1 and Hfra. In any case, our data reveal that Yfh1, differently to Hfra, could hidden a new cellular function: act per se as a shield against the metal-catalyzed intracellular oxidations.

\subsection{Effect of $\mathrm{Hfra}$ and $\mathrm{Yfh} 1$ on the $\mathrm{Cu}^{2+}$ and $\mathrm{Fe}^{3+}$-Catalyzed Formation of $\mathrm{H}_{2} \mathrm{O}_{2}$}

Under aerobic conditions, metal cations mediate the electron transfers steps from AA to $\mathrm{O}_{2}$, which is reduced to firstly form $\mathrm{H}_{2} \mathrm{O}_{2}$ and finally $\mathrm{H}_{2} \mathrm{O}$. During these processes, superoxide anion radical $\left(\mathrm{O}_{2}{ }^{\bullet-}\right)$ and hydroxyl radical $\left(\mathrm{HO}^{\bullet}\right)$ are formed as intermediates of the partial $\mathrm{O}_{2}$ reduction (Figure 1). If this occurs in vivo, both radicals but also $\mathrm{H}_{2} \mathrm{O}_{2}$, rapidly react with biomolecules causing the oxidative stress. Therefore, we also studied whether the effect of Yfh1 and Hfra on the degradation rate of AA would also have consequences on the formation of $\mathrm{O}_{2}^{\bullet-}, \mathrm{H}_{2} \mathrm{O}_{2}$, and $\mathrm{HO}^{\bullet}$.

As we proved earlier, once $\mathrm{O}_{2}{ }^{\bullet-}$ is formed, it reacts faster with free AA (towards the formation of $\mathrm{H}_{2} \mathrm{O}_{2}$ ) than with NTB (the detection probe). Hence, the formation of free $\mathrm{O}_{2}{ }^{\bullet-}$ was undetectable during the $\mathrm{Cu}^{2+}$-catalyzed AA degradation [46], nor during the $\mathrm{Fe}^{3+}$-catalyzed AA degradation (Figure S7). Consequently, we could not study the effect of Yfh1/Hfra on the formation of $\mathrm{O}_{2}{ }^{\bullet-}$. If $\mathrm{O}_{2}{ }^{\bullet-}$ takes an additional electron from AA, it evolves to $\mathrm{H}_{2} \mathrm{O}_{2}$. Both $\mathrm{Fe}^{3+}$ and $\mathrm{Cu}^{2+}$ are able to catalyze this process, although the latter has a higher catalytic efficiency (Figure 3). In fact, this correlates with their effectiveness to catalyze the AA oxidation (Figure 2).
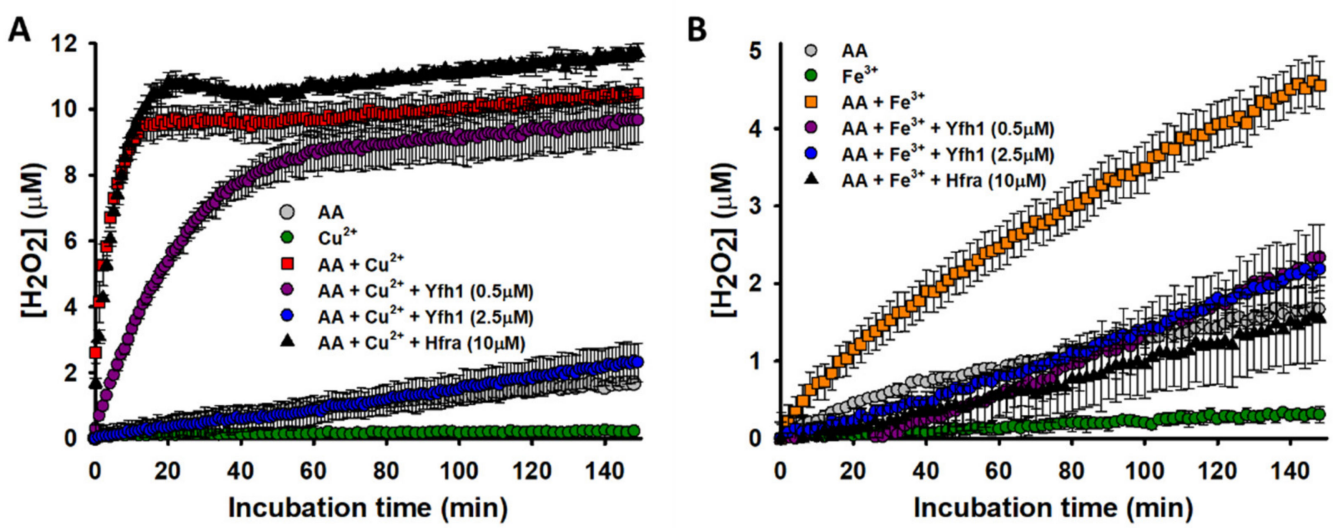

Figure 3. Effect of Hfra and Yfh1 on the formation of $\mathrm{H}_{2} \mathrm{O}_{2}$. (A) Time-dependent formation of $\mathrm{H}_{2} \mathrm{O}_{2}$ during the $\mathrm{Cu}^{2+}$-catalyzed oxidation of AA. The concentration of $\mathrm{H}_{2} \mathrm{O}_{2}$ was measured by the increase in resorufin fluorescence at $590 \mathrm{~nm}$. The different reaction mixtures contained: (i) $\mathrm{Cu}^{2+}(2.5 \mu \mathrm{M})$

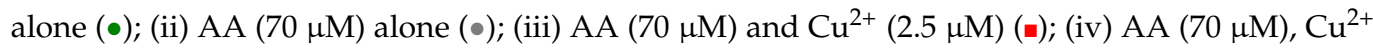
$(2.5 \mu \mathrm{M})$ and Yfh1 $(0.5 \mu \mathrm{M})(\bullet)$; (v) AA $(70 \mu \mathrm{M}), \mathrm{Cu}^{2+}(2.5 \mu \mathrm{M})$ and Yfh1 $(2.5 \mu \mathrm{M})(\bullet)$; and (vi) AA $(70 \mu \mathrm{M}), \mathrm{Cu}^{2+}(2.5 \mu \mathrm{M})$ and Hfra $(10 \mu \mathrm{M})(\mathbf{\Delta})$. (B) Time-dependent formation of $\mathrm{H}_{2} \mathrm{O}_{2}$ during the $\mathrm{Fe}^{3+}$-catalyzed oxidation of AA. The reaction mixtures contained: (i) $\mathrm{Fe}^{3+}(2.5 \mu \mathrm{M})$ alone (•); (ii) AA $(70 \mu \mathrm{M})$ alone (•); (iii) AA $(70 \mu \mathrm{M})$ and $\mathrm{Fe}^{3+}(2.5 \mu \mathrm{M})\left(\right.$ ); (iv) AA $(70 \mu \mathrm{M}), \mathrm{Fe}^{3+}(2.5 \mu \mathrm{M})$ and Yfh1 $(0.5 \mu \mathrm{M})(\bullet)$; (v) AA $(70 \mu \mathrm{M}), \mathrm{Fe}^{3+}(2.5 \mu \mathrm{M})$ and Yfh1 $(2.5 \mu \mathrm{M})(\bullet)$; and (vi) AA $(70 \mu \mathrm{M}), \mathrm{Cu}^{2+}(2.5 \mu \mathrm{M})$ and Hfra $(10 \mu \mathrm{M})(\mathbf{\Delta})$. In both panels, the data points are the mean from all experiments, and the error bars represent standard deviation from the different independent measurements.

Yfh1 was able to reduce in a concentration-dependent manner the rate of $\mathrm{Cu}^{2+}$ catalyzed formation of $\mathrm{H}_{2} \mathrm{O}_{2}$. In fact, when Yfh1 and $\mathrm{Cu}^{2+}$ were at 1:1 ratio, $\mathrm{H}_{2} \mathrm{O}_{2}$ was formed at a similar rate and yield than from the non-catalyzed degradation of AA (Figure 3A). Yfh1 also abolished the $\mathrm{Fe}^{3+}$-catalyzed formation of $\mathrm{H}_{2} \mathrm{O}_{2}$. However, it did not show a concentration-dependent effect, as even tiny amounts of Yfh1 $(0.5 \mu \mathrm{M})$ decreased the $\mathrm{H}_{2} \mathrm{O}_{2}$ formation at levels comparable with those obtained from the non-catalyzed degradation of AA (Figure 3B). This proves that Yfh1 has a higher potential to inhibit $\mathrm{H}_{2} \mathrm{O}_{2}$ formation form $\mathrm{Fe}^{3+}$-catalyzed AA oxidation than from $\mathrm{Cu}^{2+}$-catalyzed AA oxidation. 
As expected from the previously obtained data, the presence of Hfra slightly increased the $\mathrm{H}_{2} \mathrm{O}_{2}$ concentration formed from the $\mathrm{Cu}^{2+}$-catalyzed AA oxidation (Figure $3 \mathrm{~A}$ ). However, we surprisingly observed how Hfra was able to reduce the $\mathrm{Fe}^{3+}$-catalyzed formation rate of $\mathrm{H}_{2} \mathrm{O}_{2}$ at levels similar with those observed during the non-catalyzed oxidation of AA (Figure 3B).

Consequently, the obtained data prove that Yhf1 and Hfra have different roles on the formation of $\mathrm{H}_{2} \mathrm{O}_{2}$ from the metal-assisted $\mathrm{O}_{2}{ }^{\bullet-}$ reduction. While Yfh1 is able to diminish the formation of $\mathrm{H}_{2} \mathrm{O}_{2}$ independently of the metal cation acting as a catalyzer, Hfra cannot inhibit the $\mathrm{Cu}^{2+}$-catalyzed $\mathrm{H}_{2} \mathrm{O}_{2}$ formation but it has a notably effect on the $\mathrm{Fe}^{3+}$-catalyzed process. These results let us to hypothesize that, although the $\mathrm{Hfra}-\mathrm{Fe}^{3+}$ complexes accelerate the degradation rate of AA (Figure 2B), it is likely that they are also able to redirect the degradation mechanism towards the formation of other chemical species different than ROS.

\subsection{Hfra and Yfh1 Inhibit the Formation of Free Radicals from $\mathrm{Cu}^{2+}$-Catalyzed Degradation of $A A$}

If this hypothesis were true, it would be expected that the formation of the free radicals arising from the metal-catalyzed oxidation of AA would diminish in presence of frataxins. Thus, their formation from the $\mathrm{Cu}^{2+}$ - and $\mathrm{Fe}^{3+}$-catalyzed AA degradation was monitored from the decrease in the fluorescence of fluorescein $[68,69]$. While the presence of $\mathrm{Fe}^{3+}$ did not increase the production of free radicals (Figure S8A), $\mathrm{Cu}^{2+}$ highly stimulated their formation (Figure 4A). This different catalytic behavior was already described for the formation of $\mathrm{H}_{2} \mathrm{O}_{2}$, and it can be ascribed to a high oxidizing capacity of the $\mathrm{Fe}^{3+} / \mathrm{Fe}^{2+}$ pair $\left(E^{0}=0.77 \mathrm{~V}\right)$ relative to the $\mathrm{O}_{2} / \mathrm{H}_{2} \mathrm{O}_{2}\left(E^{0}=0.28 \mathrm{~V}\right)$ and the $\mathrm{H}_{2} \mathrm{O}_{2} / \mathrm{HO}^{\bullet}\left(E^{0}=0.38 \mathrm{~V}\right)$ pairs [70], which is not shown by the $\mathrm{Cu}^{2+} / \mathrm{Cu}^{+}$pair $\left(E^{0}=0.15 \mathrm{~V}\right)$.

A

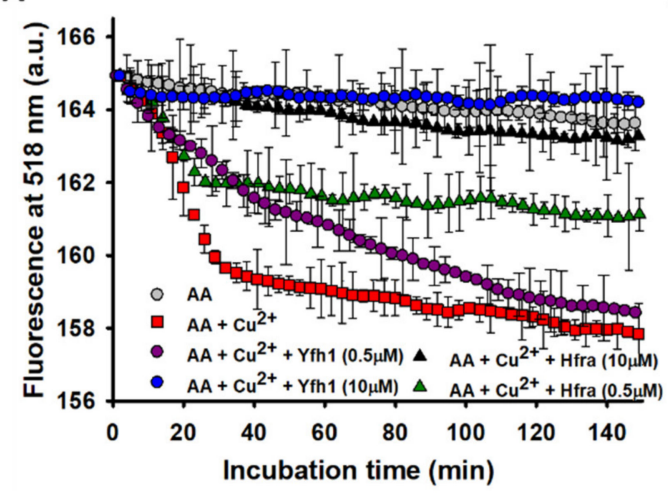

B

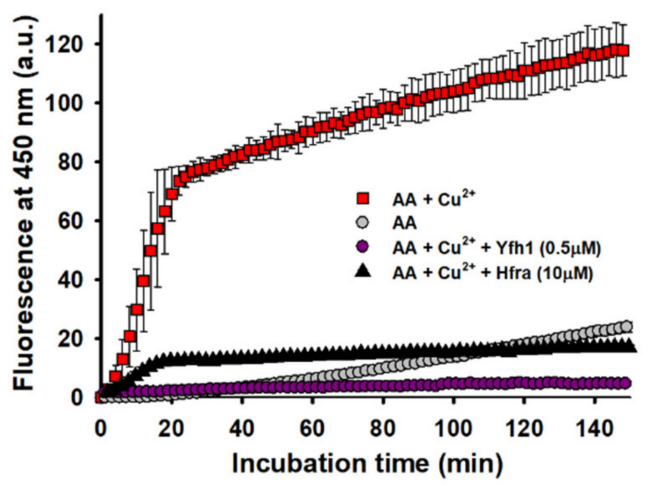

Figure 4. Effect $\mathrm{Cu}^{2+}$ on the overall free radical and hydroxyl radical $\left(\mathrm{OH}^{\bullet}\right)$ formation from the AA degradation. (A) Time-dependent overall free radical formation monitored by the decrease in the fluorescence intensity of fluorescein $\left(26 \mu \mathrm{M} ; \lambda_{\text {exc }} 490 \mathrm{~nm}\right)$ of a solution prepared in buffer B1 that contained: (i) AA (70 $\mu \mathrm{M})$ alone (•); (ii) AA $(70 \mu \mathrm{M})$ and $\mathrm{Cu}^{2+}(2.5 \mu \mathrm{M})(\mathbf{})$; (iii) AA (70 $\left.\mu \mathrm{M}\right)$, $\mathrm{Cu}^{2+}(2.5 \mu \mathrm{M})$ and Yfh1 $(0.5 \mu \mathrm{M})(\bullet)$; (iv) AA $(70 \mu \mathrm{M}), \mathrm{Cu}^{2+}(2.5 \mu \mathrm{M})$ and Yfh1 $(2.5 \mu \mathrm{M})(\bullet)$; v) AA $(70 \mu \mathrm{M}), \mathrm{Cu}^{2+}(2.5 \mu \mathrm{M})$ and Hfra $(10 \mu \mathrm{M})(\mathbf{\Delta})$; and vi) AA $(70 \mu \mathrm{M}), \mathrm{Cu}^{2+}(2.5 \mu \mathrm{M})$ and Hfra $(0.5 \mu \mathrm{M})$ $(\Delta)$. The experimental data was smoothed using the negative exponential function in Sigmaplot. (B) Time-dependent formation of $\mathrm{HO}^{\bullet}$ measured by the increase in the fluorescence of 3-CAA at $450 \mathrm{~nm}\left(\lambda_{\text {exc }}=395 \mathrm{~nm}\right)$ of a solution prepared in buffer B1 that contained: (i) AA $(70 \mu \mathrm{M})$ alone $(\bullet)$; (ii) AA $(70 \mu \mathrm{M})$ and $\mathrm{Cu}^{2+}(2.5 \mu \mathrm{M})(\mathbf{\bullet})$; (iii) AA $(70 \mu \mathrm{M}), \mathrm{Cu}^{2+}(2.5 \mu \mathrm{M})$ and Yfh1 $(0.5 \mu \mathrm{M})(\bullet)$; and (iv) AA $(70 \mu \mathrm{M}), \mathrm{Cu}^{2+}(2.5 \mu \mathrm{M})$ and Hfra $(10 \mu \mathrm{M})(\mathbf{\Delta})$. In both panels, the data points are the mean from all experiments, and the error bars represent standard deviation from the different independent measurements.

The presence of small amounts of Yfh1 $(0.5 \mu \mathrm{M})$ slightly delayed the formation of free radicals, but it did not change their final amount. However, upon increasing its concentration, the amount of free radicals was reduced to the point that their formation 
was completely inhibited at $10 \mu \mathrm{M}$ Yfh1. Regardless Hfra was not able to inhibit the formation of $\mathrm{Cu}^{2+}$-catalyzed $\mathrm{H}_{2} \mathrm{O}_{2}$, it exhibited a remarkable potential to inhibit its further reduction towards the formation of free radicals. Even its inhibitory potential was higher than that shown by Yfh1 (at $0.5 \mu \mathrm{M}$ Yfh1 was only able to reduce the formation of free radicals in $\sim 12.5 \%$, while Hfra reduced it in $\sim 50 \%$ ) (Figure $4 \mathrm{~A}$ ).

Our data prove that Yfh1 can inhibit the $\mathrm{Cu}^{2+}$ - and $\mathrm{Fe}^{3+}$-catalyzed degradation of AA, but also the formation of cell-damaging products generated during this process, such as $\mathrm{H}_{2} \mathrm{O}_{2}$ and free radicals. In contrast, Hfra accelerates the metal-catalyzed degradation of AA, as well as the $\mathrm{Cu}^{2+}$-catalyzed formation of $\mathrm{H}_{2} \mathrm{O}_{2}$, while inhibiting the $\mathrm{Fe}^{3+}$-catalyzed formation of $\mathrm{H}_{2} \mathrm{O}_{2}$. Nevertheless, Hfra showed a remarkable potential to inhibit the overall formation of free radicals, which might be biologically related to its antioxidant role.

\subsection{Hfra and $Y$ fh1 Inhibit the Formation of Hydroxyl Radical $\left(H \mathrm{H}^{\bullet}\right)$}

The effectiveness of frataxins to inhibit the formation of free radicals should be also reflected to its capacity to inhibit the $\mathrm{Fe}^{3+} / \mathrm{Cu}^{2+}$-catalyzed reduction of $\mathrm{H}_{2} \mathrm{O}_{2}$ towards the formation of $\mathrm{HO}^{\bullet}$. As expected from the fluorescein assay, $\mathrm{Fe}^{3+}$ did not increased the formation of $\mathrm{HO}^{\bullet}$ further than that formed from the non-catalyzed oxidation of AA (Figure S8B). However, the presence of $\mathrm{Cu}^{2+}$ directed the degradation of AA towards the formation of remarkable quantities of $\mathrm{HO}^{\bullet}$ (Figure $4 \mathrm{~B}$ ). The formation of $\mathrm{HO}^{\bullet}$ was completely inhibited in the presence of $0.5 \mu \mathrm{M}$ Yfh1. Hence, the free radicals formed during the AA oxidation when Yfh1 $(0.5 \mu \mathrm{M})$ was present (Figure $4 \mathrm{~A})$, must correspond to other radicals different than $\mathrm{HO}^{\bullet}$. On the other hand, Hfra was able to delay the formation rate of $\mathrm{HO}^{\bullet}$ during the first $20 \mathrm{~min}$ of incubation. After that, the $\mathrm{HO}^{\bullet}$ concentration remained constant, but $\sim 83 \%$ lower than that obtained in the absence of Hfra (Figure $4 \mathrm{~B}$ ).

Consequently, our data prove that Yfh1 is able to inhibit the free radical formation from $\mathrm{Cu}^{2+}$-catalyzed AA degradation. Hoverer, its mechanism of action is especially effective on the reduction of $\mathrm{H}_{2} \mathrm{O}_{2}$ to form $\mathrm{HO}^{\bullet}$. In addition, we demonstrate that Hfra is able to inhibit the free radical formation and consequently, it can inhibit (at least in part) the reactions yielding $\mathrm{HO}^{\bullet}$. Therefore, the direct intervention of frataxins on the reactions producing free radicals reinforce their role as part of the endogenous antioxidant machinery.

\subsection{Frataxins Do Not Undergo Oxidation upon Incubation with $\mathrm{AA}$ and $\mathrm{Fe} \mathrm{C}^{3+} / \mathrm{Cu}^{2+}$}

However, a complete comprehension of the antioxidant role of frataxins cannot be achieved without getting insights on their propensity to undergo chemical modifications concomitant to their intervention against oxidative stress. Hence, we used MALDITOF/TOF spectrometry to evaluate the oxidation level of Yfh1 and Hfra during the $\mathrm{Cu}^{2+} / \mathrm{Fe}^{3+}$-catalyzed oxidation of AA.

The molecular weight of Yfh1 did not change when it was incubated with $\mathrm{Fe}^{3+} / \mathrm{AA}$, nor with $\mathrm{Cu}^{2+} / \mathrm{AA}$ (Figure S9A,B), which proves that these oxidizing conditions are not strong enough to covalently modify Yfh1. Moreover, di-Tyr crosslinks resulting from the radical coupling to Tyr residues [51,71] were not detected between any of the three different Tyr of Yfh1, as the fluorescence emission intensity between 405-410nm did not increase [51] (Figure S10). However, we observed that Yfh1 was able to partially trap chemically synthetized $\mathrm{HO}^{\bullet}$ (Figure 5A), thus indicating that $\mathrm{HO}^{\bullet}$ radicals would be able to damage Yfh1 in case they were formed. Altogether these results prove that, although Yfh1 is prompt to be oxidized by $\mathrm{HO}^{\bullet}$, this does not occur under the conditions designed to mimic the cellular oxidative stress. In fact, this somehow self-protecting mechanism must be linked to its remarkable ability to inhibit the metal-catalyzed AA degradation and therefore, the formation of damaging ROS. 
A

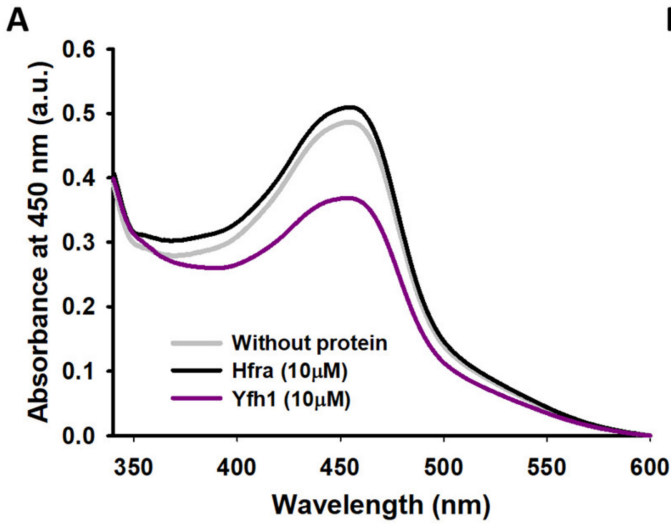

B

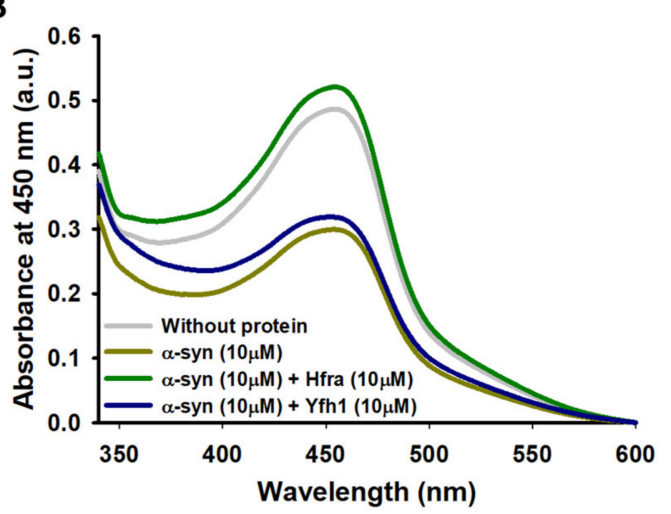

Figure 5. UV-vis spectra of the neocuproine- $\mathrm{Cu}^{+}$complex formed from the hydroxylation of salicylic acid by $\mathrm{HO}^{\bullet}$ in the absence (grey) (A,B) or in the presence of $10 \mu \mathrm{M}$ Yfh1 (purple) (A), $10 \mu \mathrm{M}$ Hfra (black) (A), $10 \mu \mathrm{M} \alpha$-syn (dark-yellow) (B), $10 \mu \mathrm{M} \alpha$-syn and $10 \mu \mathrm{M}$ Yfh1 (blue) (B), and $10 \mu \mathrm{M} \alpha$-syn and $10 \mu \mathrm{M}$ Hfra (green). All the experiments were carried out in duplicate.

In like manner, the molecular weight of Hfra was not modified when it was incubated with $\mathrm{Fe}^{3+} / \mathrm{AA}$, nor with $\mathrm{Cu}^{2+} / \mathrm{AA}$ (Figure S9C,D), thus proving that Hfra resist the chemical modifications that would induce the reaction products of the metal-catalyzed degradation of AA. In addition, any of its seven Tyr seemed to be cross-linked through the formation of di-Tyr (Figure S10). However, differently of what was observed for Yfh1, Hfra was not able to trap chemically synthetized $\mathrm{HO}^{\bullet}$ (Figure 5A), which indicates that $\mathrm{HO}{ }^{\bullet}$ seems to be harmless towards Hfra. Therefore, not even the tiny amount of $\mathrm{HO}^{\bullet}$ formed in presence of Hfra (Figure 4B) is able to damage this protein. Consequently, our results prove that Hfra is not oxidized under the conditions used to mimic the cellular oxidative stress. This occurs because Hfra has a notorious potential to inhibit the formation of free radicals, but also because it seems to be somehow resistant to the $\mathrm{HO}^{\bullet}$-induced damage.

The intervention of Yfh1 and Hfra against reactions stimulating the cellular oxidative stress could have involved their self-oxidation, which likely would have had consequences on their biological functions. However, our data conclusively prove that Yfh1 and Hfra are able to reduce the free radical formation without undergoing self-oxidation. Therefore, these results strengthen their biological role as antioxidants even further.

\subsection{Hfra and Yfh1 Are Able to Protect a-Syn Against Oxidation}

Here, we have proven that Hfra and Yfh1 might be directly integrated within the mitochondrial and cytoplasmic antioxidant machineries. If this occurs, it would be through their ability to reduce the ROS release, which indirectly involves their self-protection against oxidation. From these observations we wonder whether frataxins could also protect other intracellular proteins susceptible to oxidative modifications.

This study was carried out using $\alpha$-syn, an intrinsically disorded protein mainly found in the cytoplasm of the neurons of the substantia nigra [72]. There, $\alpha$-syn plays a broad set of physiological roles, among which highlights its ability to regulate the neurotransmission. However, $\alpha$-syn is also well-known to aggregate through the formation of intraneuronal deposits, known as Lewy bodies (LBs), which are responsible for the development of Parkinson's disease [73]. The formation of LBs is stimulated by $\alpha$-syn mutations [74]; the formation of $\alpha$-syn-metal complexes [75]; or the oxidation of $\alpha$-syn [76,77], which initiates the feed-forward cycle of oxidized $\alpha$-syn-induced stress detected in Parkinson's disease [78]. Here, we selected $\alpha$-syn as a plausible protecting target of frataxin from the results obtained by Kim et al., who proved that a Tat-fused Hfra reduced the oxidative stress in dopaminergic neurons [43]. This indicates that frataxins could protect $\alpha$-syn against oxidative stress and reduce the propensity to develop Parkinson's disease.

We have previously shown that the affinity of $\alpha$-syn towards $\mathrm{Cu}^{2+}$ (it has three binding regions with $K_{\mathrm{d}}$ between 4 and $200 \mu \mathrm{M}$ ), and the formation of the corresponding complexes, 
slightly reduced the rate of the $\mathrm{Cu}^{2+}$-catalyzed AA degradation while diminishing the formation of ROS [46]. However, this does not preclude $\alpha$-syn of being oxidized during this process, as we clearly observed a remarkable increase in its molecular weight when it was incubated with AA and $\mathrm{Cu}^{2+}$ (Figure 6A). Likely, this occurs due to the susceptibility of $\alpha$-syn to be damaged by $\mathrm{HO}^{\bullet}$ (Figure $5 \mathrm{~B}$ ), although the $\mathrm{H}_{2} \mathrm{O}_{2}$ formed during the $\mathrm{Fe}^{3+}$ catalyzed AA degradation (Figure $3 \mathrm{~B}$ ) - it is the main ROS formed during this process (Figure S8) — seems to also damage $\alpha$-syn, as its molecular weight also slightly increased when it was incubated with $\mathrm{Fe}^{3+}$ and AA (Figure S11).

Nonetheless, the molecular weight of $\alpha$-syn did not change when it was incubated with $\mathrm{Cu}^{2+} / \mathrm{Fe}^{3+}$ and AA in the presence of frataxins (Figure $6 \mathrm{~B}, \mathrm{C}$ and Figure S12), even though when the concentrations of Yfh1 or Hfra were two-fold lower. However, the protecting mechanism of Yfh 1 and Hfra on $\alpha$-syn seems to be rather different. The presence of Yfh1 only scarcely protect $\alpha$-syn to react with chemically synthetized $\mathrm{HO}^{\bullet}$ radicals (Figure 5B), thus the protecting ability of Yfh1 must be due to its intrinsic ability to inhibit the metal-catalyzed degradation of AA and the formation of ROS able to damage $\alpha$-syn. In contrast, the presence of Hfra completely protected $\alpha$-syn against free $\mathrm{HO}^{\bullet}$ radicals (Figure 5B). Hence, although Hfra is not able to inhibit the metal-catalyzed degradation of AA, it is able to direct its oxidation towards the formation of species different than ROS, but at the same time it is able to protect $\alpha$-syn against oxidative stress.
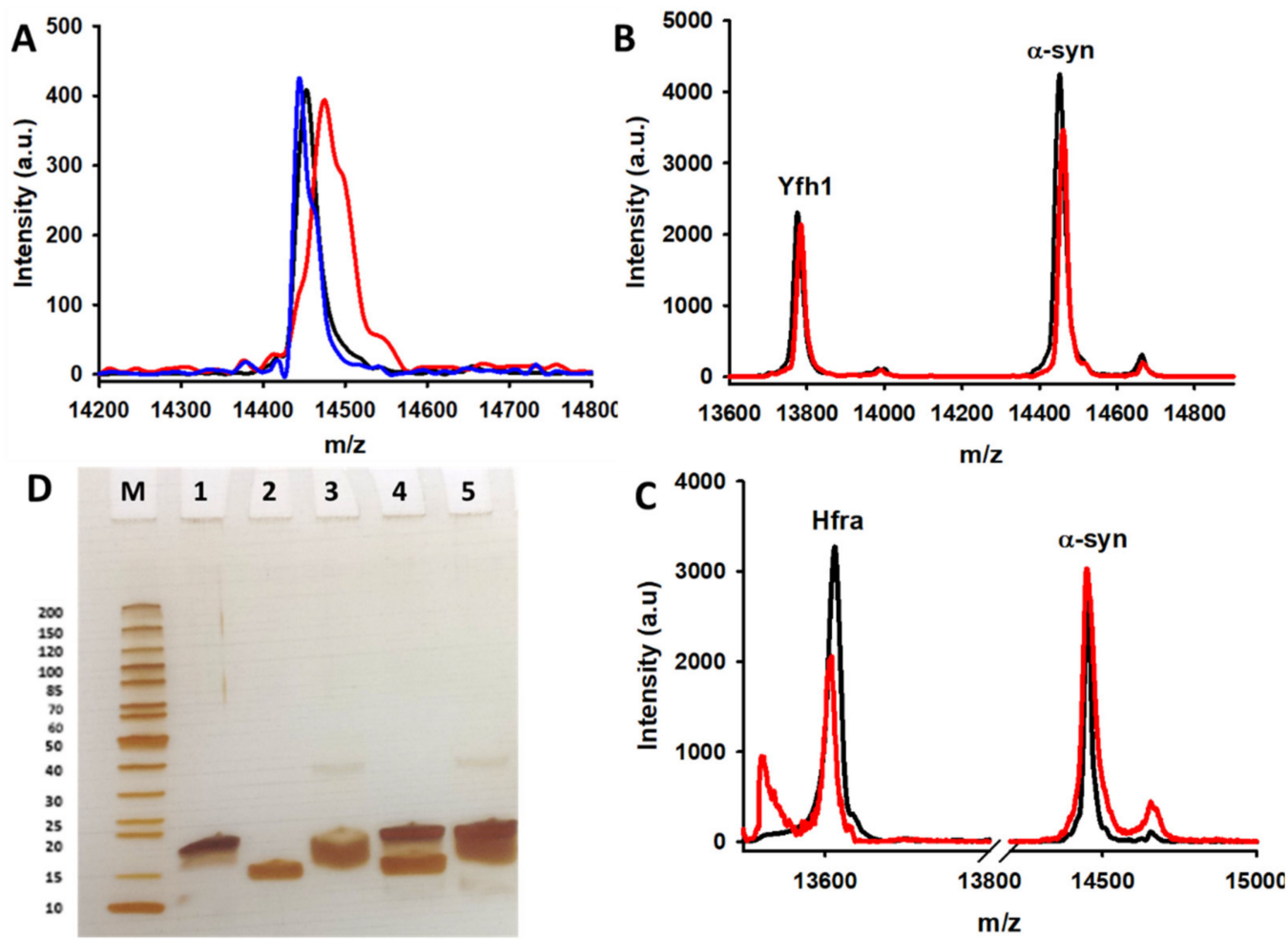

Figure 6. Studying the protective role of Yfh1 and Hfra on oxidation of $\alpha$-syn. (A) MALDI-TOF/TOF signal of $\alpha$-syn $(10 \mu \mathrm{M}$ ) incubated during $0 \mathrm{~min}$ (black) and $150 \mathrm{~min}$ (blue and red) in the presence of AA $(70 \mu \mathrm{M})($ blue $)$ or in the presence of AA $(70 \mu \mathrm{M})$ and $\mathrm{Cu}^{2+}(2.5 \mu \mathrm{M})($ red $)$. (B) MALDI-TOF/TOF signals of Yfh1 $(5 \mu \mathrm{M})$ and $\alpha$-syn $(10 \mu \mathrm{M})$ co-incubated with $\mathrm{AA}(70 \mu \mathrm{M})$ and $\mathrm{Cu}^{2+}(2.5 \mu \mathrm{M})$ during 0 min (black) and $150 \mathrm{~min}$ (red). (C) MALDI-TOF/TOF signals of Hfra $(5 \mu \mathrm{M})$ and $\alpha$-syn $(10 \mu \mathrm{M})$ coincubated with AA $(70 \mu \mathrm{M})$ and $\mathrm{Cu}^{2+}(2.5 \mu \mathrm{M})$ during $0 \mathrm{~min}$ (black) and $150 \mathrm{~min}$ (red). (D) SDS-PAGE electrophoretic gel of the analysis of reaction mixtures containing $0.1 \mathrm{mM}$ EGS and: (1) $10 \mu \mathrm{M} \alpha$-syn; (2) $10 \mu \mathrm{M}$ Hfra; (3) $10 \mu \mathrm{M}$ Yfh1; (4) $10 \mu \mathrm{M} \alpha$-syn and $10 \mu \mathrm{M}$ Hfra; and (5) $10 \mu \mathrm{M} \alpha$-syn and $10 \mu \mathrm{M}$ Yfh1. These mixtures were incubated during $30 \mathrm{~min}$ at $25^{\circ} \mathrm{C}$ before analysis. The gel includes a marker $(\mathrm{M})$ where each protein band has been labelled with its molecular weight (left). 
The obtained results prove that both frataxins are capable to protect other cytoplasmatic proteins against the oxidation induced by an unbalanced oxidative stress. In addition, our data strengthen the idea suggested by Kim et al. that frataxins can be pharmacologically used against the development of Parkinson's disease as they can avoid $\alpha$-syn oxidation and therefore, the formation of LBs.

\subsection{Protective Effect of Hfra and Yfh1 on a-Syn Does Not Involve Their Direct Binding}

The obtained data brought an intriguing question that is to know whether the presence per se of frataxins is enough to protect $\alpha$-syn or on the contrary, the protecting mechanism implies the formation of protein complexes between Yfh $1 / \mathrm{Hfra}$ and $\alpha$-syn. To investigate if frataxins were able to bind $\alpha$-syn, we performed chemical cross-linking experiments using EGS, a 16-Á linear molecule that forms covalent links between "close enough" amino groups ( $\alpha$-syn has 15 Lys residues in its sequence) [79]. SDS-PAGE analysis of cross-linked samples did not show the appearance of any band ascribable to a frataxin- $\alpha$-syn complex (Figure 6D). Moreover, MALDI-TOF/TOF data also points towards the same direction. We observed several MALDI peaks in the theoretical dimeric region, but their molecular weights correspond to Yfh1-Yfh1, Hfra-Hfra, and $\alpha$-syn- $\alpha$-syn homodimers and in any case, they were also formed in the absence of EGS. We could not detect any MALDI peak corresponding to the Yfh1- $\alpha$-syn $(\sim 28.1 \mathrm{kDa})$ or the Hfra- $\alpha$-syn $(\sim 27.9 \mathrm{kDa})$ heterodimers (Figure S13A,B).

Hence, these results indicate that frataxins do not interact with $\alpha$-syn time enough to be cross-linked, thus it is highly unlikely that they form stable complexes. Consequently, the observed protecting effect of frataxins on $\alpha$-syn do not involve their binding and the solely presence of frataxins seems to be enough to avoid $\alpha$-syn oxidation. Obviously, this is an unspecific effect, which proves that frataxins might be able to protect a broad set of cytoplasmatic molecules against the oxidative stress.

\section{Conclusions}

FRDA is a rare neurodegenerative disease caused by a deficiency in the expression levels of frataxin, a small mitochondrial protein considered as an iron-binding protein. In fact, the biological functions of frataxin are intimately related with the iron metabolism. Frataxin is able to store iron and then, transfer it to other proteins. Moreover, frataxin seems to be directly involved in the biosynthesis of the heme groups and of the Fe-S clusters. In addition, it has been suggested that frataxins (Yfh1 and Hfra but not CyaY) have a crucial role protecting cells against oxidative stress. To date, this biological function was attributed to their ability to regulate the enzymatic antioxidant defenses. However, the metal binding affinities shown by frataxins let us to hypothesize that they could directly act as part of the cellular antioxidant defense.

Here, we have proved that Yfh1 completely inhibits the $\mathrm{Cu}^{2+}$ - and the $\mathrm{Fe}^{3+}$-catalyzed degradation of AA. Therefore, $\mathrm{Yfh} 1$ is also able to diminish the formation of $\mathrm{H}_{2} \mathrm{O}_{2}$ that would appear from the $\mathrm{O}_{2}$ and the $\mathrm{O}_{2}{ }^{\bullet-}$ sequential reductions and consequently, the formation of free radicals such as $\mathrm{HO}^{\bullet}$. Although $\mathrm{Yfh} 1$ can be easily oxidized by $\mathrm{HO}^{\bullet}$, its antioxidant activity does not imply its self-oxidation basically because it does prevent the metal-catalyzed oxidations yielding ROS.

On the other hand, Hfra speeds up the $\mathrm{Cu}^{2+}$-catalyzed degradation of AA towards the formation of remarkable amounts of $\mathrm{H}_{2} \mathrm{O}_{2}$. Similarly, Hfra also accelerates the $\mathrm{Fe}^{3+}$ catalyzed degradation of AA but redirects this process towards the formation of other compounds different than $\mathrm{H}_{2} \mathrm{O}_{2}$, which likely do not contribute to the cellular oxidative stress. In any case, Hfra is able to considerably reduce the formation of free radicals (mainly $\mathrm{HO}^{\bullet}$ ) arising from both, the $\mathrm{Cu}^{2+}$ - and the $\mathrm{Fe}^{3+}$-catalyzed degradation of AA. The tiny amounts of $\mathrm{HO}^{\bullet}$ formed from these processes are unable to oxidize Hfra, which antioxidant intervention does not imply its self-oxidation.

Consequently, our work proves that Yfh1 and Hfra are essential components of the intracellular antioxidant machinery, not only because they are able to regulate the detoxify- 
ing enzymatic mechanisms, but also because they directly act against the production of ROS. This latter mechanism also has further consequences since both proteins are able to unspecifically inhibit the oxidation of $\alpha$-syn, which prove that they could act as molecular shields to protect a broad set of intracellular oxidation-prone proteins.

Supplementary Materials: The following are available online at https:/ /www.mdpi.com/2076-3 921/10/2/315/s1, Figure S1: Structural and sequential comparisons between bacterial, yeast and human frataxins; Figure S2: Representation of the hydrophobic and negatively charged residues on the tridimensional structures of frataxin; Figure S3: Effect of $\mathrm{NaCl}$ and phosphate concentration on the degradation rate of AA; Figure S4: Effect of $\mathrm{Cu}^{2+}, \mathrm{Fe}^{3+}, \mathrm{EDTA}$, and $\mathrm{O}_{2}$ on the degradation rate of AA; Figure S5: Time-dependent AA degradation in the absence of metal cations and in the presence of Yfh1 and Hfra; Figure S6: DLS studies on the $\mathrm{Cu}^{2+}$ - and $\mathrm{Fe}^{3+}$-induced oligomerization of Hfra; Figure S7: UV-vis spectroscopic study of the formation of $\mathrm{O}_{2}{ }^{\bullet-}$ radical in the presence of AA; Figure S8: $\mathrm{Effect}^{3 e^{3+}}$ on the overall free radical and hydroxyl radical $\left(\mathrm{OH}^{\bullet}\right)$ formation from the AA degradation; Figure S9: Evaluating the oxidation of frataxins during their incubation with metals and AA; Figure S10: Fluorescence study of the di-Tyr formation; Figure S11: MALDI-TOF/TOF study of the oxidation of $\alpha$-syn in the presence of AA and $\mathrm{Fe}^{3+}$; Figure S12: MALDI-TOF/TOF study of the oxidation of $\alpha$-syn in the presence of AA, $\mathrm{Fe}^{3+}$, Hfra and Yfh1; Figure S13: MALDI-TOF/TOF of the complex formation between frataxins and $\alpha$-syn; Table S1: Stoichiometry and dissociation constants determined for the complexes formed between different frataxins and iron and cooper cations.

Author Contributions: Conceptualization, M.A. and J.D.; Methodology, M.A. and B.V.; Formal analysis, A.B.U., J.F., B.V., and M.A.; Investigation, A.B.U.; Writing-original draft preparation, A.B.U. and M.A.; Writing-review and editing, A.B.U., J.D., J.F., B.V., and M.A.; Supervision, M.A. and B.V.; Funding acquisition, B.V. and J.F. All authors have read and agreed to the published version of the manuscript.

Funding: This work was cofunded by the Ministerio de Economía y Competitividad (MINECO) and by the European Regional Development Fund (FEDER) (CTQ2014-55835-R).

Institutional Review Board Statement: Not applicable.

Informed Consent Statement: Not applicable.

Data Availability Statement: Data is contained within the article or Supplementary Materials.

Acknowledgments: The authors are grateful for the excellent technical assistance from the Serveis Cientificotècnics at the UIB, especially to Rosa Gomila for her aid with the MALDI-TOF set up and analysis. We are also indebted with Annalisa Pastore (King's College London) for inspiring this research.

Conflicts of Interest: The authors declare no conflict of interest.

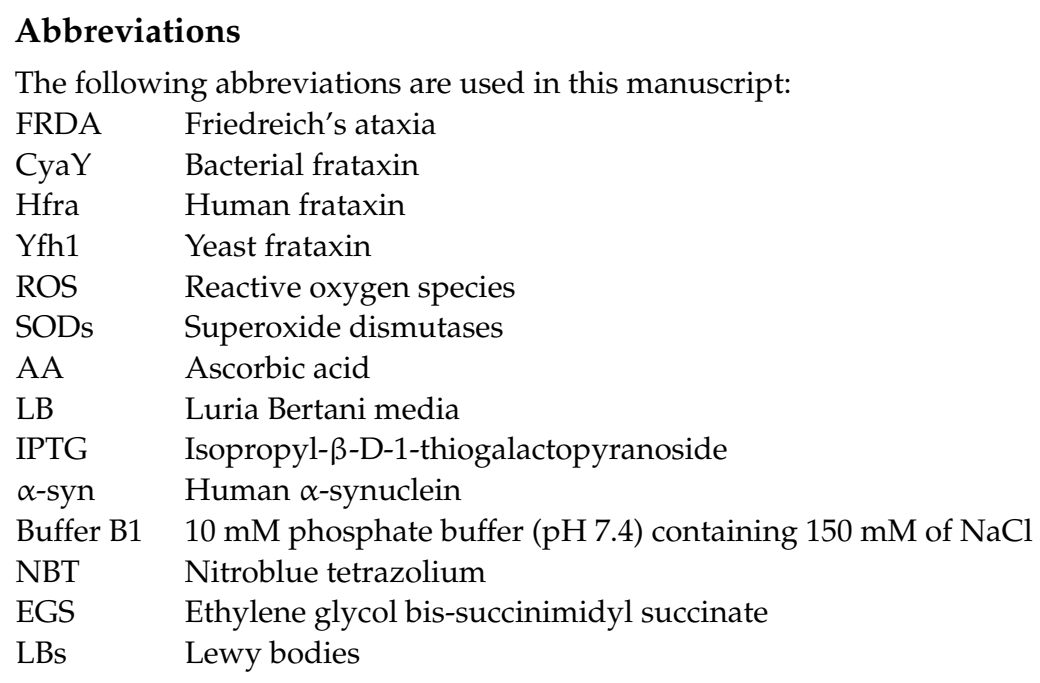




\section{References}

1. Vankan, P. Prevalence gradients of Friedreich's ataxia and R1b haplotype in Europe co-localize, suggesting a common Palaeolithic origin in the Franco-Cantabrian ice age refuge. J. Neurochem. 2013, 126 (Suppl. 1), 11-20. [CrossRef] [PubMed]

2. Cook, A.; Giunti, P. Friedreich's ataxia: Clinical features, pathogenesis and managemen. Br. Med. Bull. 2017, 124, 19-30. [CrossRef]

3. Campuzano, V.; Montermini, L.; Moltò, M.D.; Pianese, L.; Cossée, M.; Cavalcanti, F.; Monros, E.; Rodius, F.; Duclos, F.; Monticelli, A.; et al. Friedreich's ataxia: Autosomal recessive disease caused by an intronic GAA triplet repeat expansion. Science 1996, 271, 1423-1427. [CrossRef] [PubMed]

4. Pandolfo, M. Friedreich ataxia: The clinical picture. J. Neurol. 2009, 256, 3-8. [CrossRef]

5. Adinolfi, S.; Trifuoggi, M.; Politou, A.S.; Martin, S.; Pastore, A. A structural approach to understanding the iron-binding properties of phylogenetically different frataxins. Hum. Mol. Genet. 2002, 11, 1865-1877. [CrossRef]

6. Bousette, N.; Kislinger, T.; Fong, V.; Isserlin, R.; Hewel, J.A.; Emili, A.; Gramolini, A.O. Large-scale characterization and analysis of the murine cardiac proteome. J. Prot. Res. 2009, 8, 1887-1890. [CrossRef]

7. Schmucker, S.; Argentini, M.; Carelle-Calmels, N.; Martelli, A.; Puccio, H. The in vivo mitochondrial two-step maturation of human frataxin. Hum. Mol. Genet. 2008, 17, 3521-3531. [CrossRef] [PubMed]

8. Musco, G.; Stier, G.; Kolmerer, B.; Adinolfi, S.; Martin, S.; Frenkiel, T.; Gibson, T.; Pastore, A. Towards a structural understanding of Friedreich's ataxia: The solution structure of frataxin. Structure 2000, 8, 695-707. [CrossRef]

9. Huynen, M.A.; Snel, B.; Bork, P.; Gibson, T.J. The phylogenetic distribution of frataxin indicates a role in iron-sulfur cluster protein assembly. Hum. Mol. Genet. 2001, 10, 2463-2468. [CrossRef] [PubMed]

10. Pastore, C.; Franzese, M.; Sica, F.; Temussi, P.; Pastore, A. Understanding the binding properties of an unusual metal-binding protein-A study of bacterial frataxin. FEBS J. 2007, 274, 4199-4210. [CrossRef]

11. Han, T.-H.-L.; Camadro, J.M.; Santos, R.; Lesuisse, E.; El Hage Chahine, J.M.; Ha-Duong, N.T. Mechanisms of Iron and CopperFrataxin Interactions. Metallomics 2017, 9, 1073-1085. [CrossRef] [PubMed]

12. Noguera, M.E.; Roman, E.A.; Rigal, J.B.; Cousido-Siah, A.; Mitschler, A.; Podjarny, A.; Santos, J. Structural characterization of metal binding to a cold-adapted frataxin. J. Biol. Inorg. Chem. 2015, 20, 653-664. [CrossRef] [PubMed]

13. Castro, I.H.; Pignataro, M.F.; Sewell, K.E.; Espeche, L.D.; Herrera, M.G.; Noguera, M.E.; Dain, L.; Nadra, A.D.; Aran, M.; Smal, C.; et al. Frataxin Structure and Function. Subcell. Biochem. 2019, 93, 393-438.

14. Anzovino, A.; Lane, D.J.R.; Huang, M.L.-H.; Richardson, D.R. Fixing frataxin: 'ironing out' the metabolic defect in Friedreich's ataxia. Br. J. Pharmacol. 2014, 171, 2174-2190. [CrossRef]

15. Zanella, I.; Derosas, M.; Corrado, M.; Cocco, E.; Cavadini, P.; Biasiotto, G.; Poli, M.; Verardi, R.; Arosio, P. The effects of frataxin silencing in HeLa cells are rescued by the expression of human mitochondrial ferritin. Biochim. Biophys. Acta 2008, 1782, 90-98. [CrossRef] [PubMed]

16. Karlberg, T.; Schagerlöf, U.; Gakh, O.; Park, S.; Ryde, U.; Lindahl, M.; Leath, K.; Garman, E.; Isaya, G.; Al-Karadaghi, S. The Structures of Frataxin Oligomers Reveal the Mechanism for the Delivery and Detoxification of Iron. Structure 2006, 14, 1535-1546. [CrossRef]

17. Lesuisse, E.; Santos, R.; Matzanke, B.F.; Knight, S.A.; Camadro, J.M.; Dancis, A. Iron use for haeme synthesis is under control of the yeast frataxin homologue (Yfh1). Hum. Mol. Genet. 2003, 12, 879-888. [CrossRef] [PubMed]

18. Soderberg, C.; Gillam, M.E.; Ahlgren, E.C.; Hunter, G.A.; Gakh, O.; Isaya, G.; Ferreira, G.C.; Al-Karadaghi, S. The Structure of the Complex between Yeast Frataxin and Ferrochelatase: Characterization and pre-steady state reaction of ferrous iron delivery and heme synthesis. J. Biol. Chem. 2016, 291, 11189-11887. [CrossRef]

19. Steinkellner, H.; Singh, H.N.; Muckenthaler, M.U.; Goldenberg, H.; Moganty, R.R.; Scheiber-Mojdehkar, B.; Sturm, B. No changes in heme synthesis in human Friedreich's ataxia erythroid progenitor cells. Gene 2017, 621, 5-11. [CrossRef]

20. Yoon, T.; Cowan, J.A. Frataxin-mediated iron delivery to ferrochelatase in the final step of heme biosynthesis. J. Biol. Chem. 2004, 279, 25943-25946. [CrossRef]

21. Foury, F. Low Iron Concentration and Aconitase Deficiency in a Yeast Frataxin Homologue Deficient Strain. FEBS Lett. 1999, 456, 281-284. [CrossRef]

22. Chen, O.S.; Hemenway, S.; Kaplan, J. Inhibition of Fe-S cluster biosynthesis decreasesmitochondrial iron export: Evidence that Yfh1p affects Fe-S cluster synthesis. Proc. Natl. Acad. Sci. USA 2002, 99, 12321-12326. [CrossRef]

23. Boniecki, M.T.; Freibert, S.A.; Muhlenhoff, U.; Lill, R.; Cygler, M. Structure and functional dynamics of the mitochondrial Fe/S cluster synthesis complex. Nat. Commun. 2017, 8, 1287. [CrossRef] [PubMed]

24. Gervason, S.; Larkem, D.; Mansour, A.B.; Botzanowski, T.; Müller, C.S.; Pecqueur, L.; Le Pavec, G.; Delaunay-Moisan, A.; Brun, O.; Agramunt, J.; et al. Physiologically relevant reconstitution of iron-sulfur cluster biosynthesis uncovers persulfide-processing functions of ferredoxin-2 and frataxin. Nat. Commun. 2019, 10, 3566. [CrossRef] [PubMed]

25. Fox, N.G.; Das, D.; Chakrabarti, M.; Lindahl, P.A.; Barondeau, D.P. Frataxin accelerates [2Fe-2S] cluster formation on the human Fe-S assembly complex. Biochemistry 2015, 54, 3880-3889. [CrossRef] [PubMed] 
26. Soriano, S.; Calap-Quintana, P.; Llorens, J.V.; Al-Ramahi, I.; Gutiérrez, L.; Martínez-Sebastián, M.J.; Botas, J.; Moltó, M.D. Metal Homeostasis Regulators Suppress FRDA Phenotypes in a Drosophila Model of the Disease. PLoS ONE 2016, 11, e0159209. [CrossRef]

27. Wong, A.; Yang, J.; Cavadini, P.; Gellera, C.; Lonnerdal, B.; Taroni, F.; Cortopassi, G. The Friedreich's ataxia mutation confers cellular sensitivity to oxidant stress which is rescued by chelators of iron and calcium and inhibitors of apoptosis. Hum. Mol. Genet. 1999, 8, 425-430. [CrossRef] [PubMed]

28. Lupoli, F.; Vannocci, T.; Longo, G.; Niccolai, N.; Pastore, A. The role of oxidative stress in Friedreich's ataxia. FEBS Lett. 2018, 592, 718-727. [CrossRef] [PubMed]

29. Haugen, A.C.; Di Prospero, N.A.; Parker, J.S.; Fannin, R.D.; Chou, J.; Meyer, J.N.; Halweg, C.; Collins, J.B.; Durr, A.; Fischbeck, K.; et al. Altered gene expression and DNA damage in peripheral blood cells from Friedreich's ataxia patients: Cellular model of pathology. PLoS Genet. 2010, 6, e1000812. [CrossRef] [PubMed]

30. Thierbach, R.; Drewes, G.; Fusser, M.; Voigt, A.; Kuhlow, D.; Blume, U.; Schulz, T.J.; Reiche, C.; Glatt, H.; Epe, B.; et al. The Friedreich's ataxia protein frataxin modulates DNA base excision repair in prokaryotes and mammals. Biochem. J. 2010, 432, 165-172. [CrossRef] [PubMed]

31. Runko, G.A.; Min, K. Overexpression of Frataxin in the Mitochondria Increases Resistance to Oxidative Stress and Extends Lifespan in Drosophila. FEBS Lett. 2008, 582, 715-719. [CrossRef]

32. Gomes, C.M.; Santos, R. Neurodegeneration in Friedreich's ataxia: From defective frataxin to oxidative stress. Oxid. Med. Cell. Longev. 2013, 2013, 487534. [CrossRef] [PubMed]

33. D'Oria, V.; Petrini, S.; Travaglini, L.; Priori, C.; Piermarini, E.; Petrillo, S.; Carletti, B.; Bertini, E.; Piemonte, F. Frataxin Deficiency Leads to Reduced Expression and Impaired Translocation of NF-E2-Related Factor (Nrf2) in Cultured Motor Neurons. Int. J. Mol. Sci. 2013, 14, 7853-7865.

34. Shan, Y.; Schoenfeld, R.A.; Hayashi, G.; Napoli, E.; Akiyama, T.; Carstens, M.I.; Carstens, E.E.; Pook, M.A.; Cortopassi, G.A. Frataxin deficiency leads to defects in expression of antioxidants and Nrf2 expression in dorsal root ganglia of the Friedreich's ataxia YG8R mouse model. Antioxid. Redox Signal. 2013, 19, 1481-1493. [CrossRef] [PubMed]

35. Shelton, P.; Jaiswal, A.K. The transcription factor NF-E2-related factor 2 (Nrf2): A protooncogene? FASEB J. 2013, $27,414-423$. [CrossRef]

36. Jiralerspong, S.; Ge, B.; Hudson, T.J.; Pandolfo, M. Manganese superoxide dismutase induction by iron is impaired in Friedreich ataxia cells. FEBS Lett. 2001, 509, 101-105. [CrossRef]

37. Han, T.-H.-L.; Camadro, J.M.; Barbault, F.; Santos, R.; El Hage Chahine, J.M.; Ha-Duong, N.T. In Vitro interaction between yeast frataxin and superoxide dismutases: Influence of mitochondrial metals. Biochim. Biophys. Acta Gen. Subj. 2019, 1863, 883-892. [CrossRef]

38. Rotig, A.; de Lonlay, P.; Chretien, D.; Foury, F.; Koenig, M.; Sidi, D.; Munnich, A.; Rustin, P. Aconitase and mitochondrial iron-sulphur protein deficiency in Friedreich ataxia. Nat. Genet. 1997, 17, 215-217. [CrossRef]

39. Park, S.; Gakh, O.; Mooney, S.; Isaya, G. The Ferroxidase Activity of Yeast Frataxin. J. Biol. Chem. 2002, 277, 38589-38595. [CrossRef] [PubMed]

40. Ding, H.; Yang, J.; Coleman, L.C.; Yeung, S. Distinct iron binding property of two putative iron donors for the iron-sulfur cluster assembly: IscA and the bacterial frataxin ortholog CyaY under physiological and oxidative stress conditions. J. Biol. Chem. 2007, 282, 7997-8004. [CrossRef]

41. Li, D.S.; Ohshima, K.; Jiralerspong, S.; Bojanowski, M.W.; Pandolfo, M. Knock-out of the CyaY gene in Escherichia coli does not affect cellular iron content and sensitivity to oxidants. FEBS Lett. 1999, 456, 13-16. [CrossRef]

42. Condò, I.; Ventura, N.; Malisan, F.; Tomassini, B.; Testi, R. A Pool of Extramitochondrial Frataxin That Promotes Cell Survival. J. Biol. Chem. 2006, 281, 16750-16755. [CrossRef] [PubMed]

43. Kim, M.; Kim, D.; Jeong, H.; Sohn, E.J.; Shin, M.J.; Ahn, E.H.; Kwon, S.W.; Kim, Y.N.; Kim, D.S.; Park, J.; et al. Tat-Frataxin Protects Dopaminergic Neuronal Cells against MPTP-Induced Toxicity in a Mouse Model of Parkinson's Disease. Biochimie 2012, 94, 2448-2456. [CrossRef] [PubMed]

44. Britti, E.; Delaspre, F.; Feldman, A.; Osborne, M.; Greif, H.; Tamarit, J.; Ros, J. Frataxin-Deficient Neurons and Mice Models of Friedreich Ataxia Are Improved by TAT-MTScs-FXN Treatment. J. Cell. Mol. Med. 2018, 22, 834-848. [CrossRef]

45. He, Y.; Alam, S.L.; Proteasa, S.V.; Zhang, Y.; Lesuisse, E.; Dancis, A.; Stemmler, T.L. Yeast frataxin solution structure, iron binding, and ferrochelatase interaction. Biochemistry 2004, 43, 16254-16262. [CrossRef]

46. Martínez-Orozco, H.; Mariño, L.; Uceda, A.B.; Ortega-Castro, J.; Vilanova, B.; Frau, J.; Adrover, M. Nitration and Glycation Diminish the $\alpha$-Synuclein Role in the Formation and Scavenging of Cu2+-Catalyzed Reactive Oxygen Species. ACS Chem. Neurosci. 2019, 10, 2919-2930. [CrossRef] [PubMed]

47. Hong, L.; Simon, J.D. Binding of $\mathrm{Cu}(\mathrm{II})$ to human alpha-synucleins: Comparison of wild type and the point mutations associated with the familial Parkinson's disease. J. Phys. Chem. B 2009, 113, 9551-9561. [CrossRef] [PubMed]

48. Bryant, S.M.; Lynch, R.E.; Hill, H.R. Kinetic analysis of superoxide anion production by activated and resident murine peritoneal macrophages. Cell Immunol. 1982, 69, 46-58. [CrossRef] 
49. Sirota, T.V. Use of nitro blue tetrazolium in the reaction of adrenaline autooxidation for the determination of superoxide dismutase activity. Biochem. Moscow Suppl. Ser. B 2012, 6, 254-260. [CrossRef]

50. Manevich, Y.; Held, K.D.; Biaglow, J.E. Coumarin-3-carboxylic acid as a detector for hydroxyl radicals generated chemically and by gamma radiation. Radiat. Res. 1997, 148, 580-591. [CrossRef] [PubMed]

51. Al-Hilaly, Y.K.; Biasetti, L.; Blakeman, B.J.; Pollack, S.J.; Zibaee, S.; Abdul-Sada, A.; Thorpe, J.R.; Xue, W.F.; Serpell, L.C. The involvement of dityrosine crosslinking in $\alpha$-synuclein assembly and deposition in Lewy Bodies in Parkinson's disease. Sci. Rep. 2016, 6, 39171. [CrossRef]

52. Ozyürek, M.; Bektaşoğlu, B.; Güçlü, K.; Apak, R. Hydroxyl radical scavenging assay of phenolics and flavonoids with a modified cupric reducing antioxidant capacity (CUPRAC) method using catalase for hydrogen peroxide degradation. Anal. Chim. Acta 2008, 616, 196-206. [CrossRef]

53. Özyürek, M.; Güçlü, K.; Apak, R. The main and modified CUPRAC methods of antioxidant measurement. Trends Analyt. Chem. 2011, 30, 652-664. [CrossRef]

54. Cavadini, P.; Gellera, C.; Patel, P.I.; Isaya, G. Human frataxin maintains mitochondrial iron homeostasis in Saccharomyces cerevisiae. Hum. Mol. Genet. 2000, 9, 2523-2530. [CrossRef] [PubMed]

55. Koeppen, A.H.; Ramirez, R.L.; Yu, D.; Collins, S.E.; Qian, J.; Parsons, P.J.; Yang, K.X.; Chen, Z.; Mazurkiewicz, J.E.; Feustel, P.J. Friedreich's ataxia causes redistribution of iron, copper, and zinc in the dentate nucleus. Cerebellum 2012, 11, 845-860. [CrossRef] [PubMed]

56. Covarrubias-Pinto, A.; Acuña, A.I.; Beltrán, F.A.; Torres-Díaz, L.; Castro, M.A. Old things new view: Ascorbic acid protects the brain in neurodegenerative disorders. Int. J. Mol. Sci. 2015, 16, 28194-28217. [CrossRef]

57. Harrison, F.E.; May, J.M. Vitamin C function in the brain: Vital role of the ascorbate transporter SVCT2. Free Radic. Biol. Med. 2009, 46, 719-730. [CrossRef]

58. Gaggelli, E.; Kozlowski, H.; Valensin, D.; Valensin, G. Copper homeostasis and neurodegenerative disorders (Alzheimer's, prion, and Parkinson's diseases and amyotrophic lateral sclerosis). Chem. Rev. 2006, 106, 1995-2044. [CrossRef] [PubMed]

59. Khan, M.M.; Martell, A.E. Metal ion and metal chelate catalyzed oxidation of ascorbic acid by molecular oxygen. II. Cupric and ferric chelate catalyzed oxidation. J. Am. Chem. Soc. 1967, 89, 7104-7111.

60. Guilloreau, L.; Combalbert, S.; Sournia-Saquet, A.; Mazarguil, H.; Faller, P. Redox chemistry of copper-amyloid-beta: The generation of hydroxyl radical in the presence of ascorbate is linked to redox-potentials and aggregation state. ChemBioChem 2007, 8, 1317-1325. [CrossRef]

61. Khan, M.M.; Martell, A.E. Metal ion and metal chelate catalyzed oxidation of ascorbic acid by molecular oxygen. I. Cupric and ferric ion catalyzed oxidation. J. Am. Chem. Soc. 1967, 89, 4176-4185.

62. Harel, S. Oxidation of Ascorbic Acid and Metal Ions as Affected by NaCl. J. Agric. Food Chem. 1994, 42, 2402-2406. [CrossRef]

63. Kastelic, M.; Kalyuzhnyi, Y.; Hribar, L.B.; Dill, K.A.; Vlachy, V. Protein Aggregation in Salt Solutions. Proc. Natl. Acad. Sci. USA 2015, 112, 6766-6770. [CrossRef] [PubMed]

64. Pastore, A.; Puccio, H. Frataxin: A protein in serach for a function. J. Neurochem. 2013, 126 (Suppl. 1), 43-52. [CrossRef]

65. Han, T.-H.-L. Functional Studies of Frataxin: Relations with Metal Homeostasis and Oxidatives Stress. Ph.D. Thesis, Université Sorbonne Paris Cité, Paris, France, 2016. Available online: https://tel.archives-ouvertes.fr/tel-01929004 (accessed on 1 December 2020).

66. Park, S.; Gakh, O.; O’Neill, H.A.; Mangravita, A.; Nichol, H.; Ferreira, G.C.; Isaya, G. Yeast frataxin sequentially chaperones and stores iron by coupling protein assembly with iron oxidation. J. Biol. Chem. 2003, 278, 31340-31351. [CrossRef] [PubMed]

67. Ahlgren, E.-C.; Fekry, M.; Wiemann, M.; Söderberg, C.A.; Bernfur, K.; Gakh, O.; Rasmussen, M.; Højrup, P.; Emanuelsson, C.; Isaya, G.; et al. Iron-induced oligomerization of human FXN81-210 and bacterial CyaY frataxin and the effect of iron chelators. PLOS ONE 2017, 12, e0188937.

68. Ou, B.; Hampsch-Woodill, M.; Flanagan, J.; Deemer, E.K.; Prior, R.L.; Huang, D. Novel fluorometric assay for hydroxyl radical prevention capacity using fluorescein as the probe. J. Agric. Food. Chem. 2002, 50, 2772-2777. [CrossRef]

69. Ahmad, M.F.; Singh, D.; Taiyab, A.; Ramakrishna, T.; Bakthisaran, R.; Rao, C.M. Selective Cu2+ binding, redox silencing, and cytoprotective effects of the small heat shock proteins $\alpha \mathrm{A}$ - and $\alpha \mathrm{B}$-crystallin. J. Mol. Biol. 2008, 382, 812-824. [CrossRef]

70. Wood, P.M. The potential diagram for oxygen at pH 7. Biochem. J. 1988, 253, 287-289. [CrossRef]

71. Paik, S.R.; Shin, H.J.; Lee, J.H. Metal-catalyzed oxidation of alpha-synuclein in the presence of copper(II) and hydrogen peroxide. Arch. Biochem. Biophys. 2000, 378, 269-277. [CrossRef]

72. Theillet, F.X.; Binolfi, A.; Bekei, B.; Martorana, A.; Rose, H.M.; Stuiver, M.; Verzini, S.; Lorenz, D.; van Rossum, M.; Goldfarb, D.; et al. Structural disorder of monomeric $\alpha$-synuclein persists in mammalian cells. Nature 2016, 530, 45-50. [CrossRef] [PubMed]

73. Goedert, M. Alpha-synuclein and neurodegenerative diseases. Nat. Rev. Neurosci. 2001, 2, 492-501. [CrossRef] [PubMed]

74. Xu, L.; Pu, J. Alpha-synuclein in Parkinson's disease: From pathogenetic dysfunction to potential clinical application. Parkinsons Dis. 2016, 2016, 1720621. [CrossRef] [PubMed]

75. Uversky, V.N.; Li, J.; Fink, A.L. Metal-triggered structural transformations, aggregation, and fibrillation of human alpha-synuclein. A possible molecular NK between Parkinson's disease and heavy metal exposure. J. Biol. Chem. 2001, 276, 44284-44296. [CrossRef] 
76. Souza, J.M.; Giasson, B.I.; Chen, Q.; Lee, V.M.; Ischiropoulos, H. Dityrosine cross-linking promotes formation of stable alphasynuclein polymers. Implication of nitrative and oxidative stress in the pathogenesis of neurodegenerative synucleinopathies. $J$. Biol. Chem. 2000, 275, 18344-18349. [CrossRef] [PubMed]

77. Hashimoto, M.; Hsu, X.Y.; Takeda, A.; Sisk, A.; Sundsmo, M.; Masliah, E. Oxidative stress induces amyloid-like aggregate formation of NACP / $\alpha$-synuclein in vitro. Neuroreport 1999, 10, 717-721. [CrossRef]

78. Andersen, J.K. Oxidative stress in neurodegeneration: Cause or consequence? Nat. Med. 2004, 10, S18-S25. [CrossRef] [PubMed]

79. Kluger, R.; Alagic, A. Chemical cross-linking and protein-protein interactions-a review with illustrative protocols. Bioorg. Chem. 2004, 32, 451-472. [CrossRef] [PubMed] 